\title{
Light Detection and Ranging (LiDAR) and Multispectral Scanner (MSS) Studies Examine Coastal Environments Influenced by Mining
}

W. Charles Kerfoot ${ }^{1}{ }^{*}$, Martin M. Hobmeier ${ }^{1}$, Foad Yousef ${ }^{1}$, Sarah A. Green ${ }^{1,2}$, Robert Regis ${ }^{3}$, Colin N. Brooks ${ }^{4}$, Robert Shuchman ${ }^{3,4}$, Jamey Anderson ${ }^{1}$ and Molly Reif ${ }^{5}$

1 Great Lakes Research Center and Department of Biological Sciences, Michigan Technological University, Houghton, MI 49931, USA; E-Mails: mmhobmei@mtu.edu (M.M.H.); fyousef@mtu.edu (F.Y.); sgreen@mtu.edu (S.A.G.); jameya@mtu.edu (J.A.) Department of Chemistry, Michigan Technological University, Houghton, MI 49931, USA

3 Department of Geological and Mining Engineering and Sciences, Michigan Technological University, Houghton, MI 49931, USA; E-Mails: rregis@nmu.edu (R.R.); shuchman@mtu.edu (R.S.)

4 Michigan Tech Research Institute, Ann Arbor, MI 48105, USA; E-Mail: cnbrooks@ mtu.edu

5 US Army Corps of Engineers Engineer Research and Development Center, Environmental Laboratory, Joint Airborne LiDAR Bathymetry Technical Center of Expertise, Kiln, MS 39556, USA; E-Mail: Molly.K.Reif@usace.army.mil

* Author to whom correspondence should be addressed; E-Mail: wkerfoot@ mtu.edu; Tel.: +1-906-487-2791; Fax: +1-906-487-1029.

Received: 28 November 2013; in revised form: 20 December 2013 / Accepted: 10 January 2014 / Published: 27 January 2014

\footnotetext{
Abstract: There are numerous examples of past and present mine disposal into freshwater and marine coastal bays and riverine environments. Due to its high spatial resolution and extended water penetration, coastal light detection and ranging (LiDAR), coupled with multispectral scanning (MSS), has great promise for resolving disturbed shoreline features in low turbidity environments. Migrating mine tailings present serious issues for Lake Superior and coastal marine environments. Previous investigations in Lake Superior uncovered a metal-rich "halo" around the Keweenaw Peninsula, related to past copper mining practices. For over a century, waste rock migrating from shoreline tailing piles has moved along extensive stretches of coastline, compromising critical fish breeding grounds, damming stream outlets, transgressing into wetlands and along recreational beaches and
} 
suppressing benthic invertebrate communities. In Grand (Big) Traverse Bay, Buffalo Reef is an important spawning area for lake trout and whitefish threatened by drifting tailings. The movement of tailings into Buffalo Reef cobble fields may interfere with the hatching of fish eggs and fry survival, either by filling in crevices where eggs are deposited or by toxic effects on eggs, newly hatched larvae or benthic communities. Here, we show that the coastal tailing migration is not "out of sight, out of mind", but clearly revealed by using a combination of LiDAR and MSS techniques.

Keywords: LiDAR; MSS; mining; coastal; stamp sands

\section{Introduction}

We combined two complementary remote sensing techniques to examine the issue of mining impacts in coastal regions, specifically to address the recent "out of sight, out of mind" mentality of discharging tailings into coastal environments. One technique, light detection and ranging (LiDAR), is an active remote sensing approach, used here in the ALS (airborne laser scanning) version, where an airborne laser-ranging system acquires high-resolution elevation and bathymetric data [1]. The Compact Hydrographic Airborne Rapid Total Survey (CHARTS) LiDAR data (see the Methods) are collected with aircraft-mounted lasers capable of recording measurements at a rate of $10-2,000-\mathrm{kHz}$ pulses for above-water topographic surveys and $1-10-\mathrm{kHz}$ for coastal water-penetrating bathymetric surveys, with a vertical precision of $\pm 15 \mathrm{~cm}$ [2]. In coastal surveys, an aircraft travels over a water stretch at about $60 \mathrm{~m} \cdot \mathrm{s}^{-1}$, pulsing two varying laser beams toward Earth through an opening in the plane's fuselage: an infrared wavelength beam that is reflected off the water surface and a narrow, blue-green wavelength beam that penetrates the water surface and is reflected off the sediment or underwater substrate surface (Figure 1). The LiDAR sensor records the time difference between the two signals to derive detailed measurements of water depth and bottom bathymetry. Under ideal conditions in coastal waters, blue-green laser penetration allows the detection of bottom structures to a depth of approximately three times passive light reflection, i.e., as deep as $22 \mathrm{~m}$ in the northern Great Lakes [3] and up to $40 \mathrm{~m}$ in oceanic environments [4].

Another technique, multispectral scanning (MSS), utilizes a different approach to characterize bottom sediments. This approach acquires passive reflectance images in many discrete spectral bands throughout the ultraviolet, visible, near-infrared, mid-infrared and thermal portion of the spectrum. The systems are thus color-dependent and can discriminate above- and below-water features that have diagnostic absorption and reflectance characteristics. In our case, keying off albedo and spectral differences of substrates, MSS was used jointly with LiDAR as a powerful tool to characterize tailing dispersal along the Grand (Big) Traverse Bay shoreline of the Keweenaw Peninsula and the encroachment of tailings onto Buffalo Reef, an important fish spawning area. Our overall objective here is to identify key disturbances to coastal ecosystem processes by migrating historic mining waste.

Although the example discussed here deals with particular regional features (bedrock composition, coastal shelf bathymetry, tailing albedo), we stress that there is an opportunity to apply techniques to address an extensive mining legacy scattered about the watersheds and shorelines of Lake Superior and 
northern Lake Huron [5-8]. The Lake Superior Basin is recognized for centuries of iron, copper, zinc, silver and gold mining [8]. Copper enrichments in Lake Superior sediments originated from several intensively mined regions: the Keweenaw Peninsula of Michigan and the Thunder Bay, Marathon, Wawa, and Sault Ste. Marie regions of Ontario, Canada. Sediment investigations have revealed a major metal halo around the Keweenaw Peninsula related to historic copper mining activities [9-11]. Here, we use LiDAR and MSS, high definition side-scan sonar and cameras on remote operating vehicles (ROVs), i.e., instruments with increasing spatial resolution, to illustrate in detail how the coastal ecosystem is being disturbed by migrating mining wastes.

Figure 1. The Compact Hydrographic Airborne Rapid Total Survey (CHARTS) system (see the Methods) operated from a fixed wing King Air Beechcraft 2000, shown with the crew at the Houghton County Memorial Airport. For light detection and ranging (LiDAR), two laser pulses (blue-green $532 \mathrm{~nm}$ and near-IR 1,064 nm) are directed downward towards the lake water surface. The near-IR reflects from the water surface, whereas the blue-green penetrates through the water column and reflects off the lakebed. The difference between the two returning pulses gives the depth of the water column (bathymetry) and reveals the fine details of the benthic structure (the plane diagram is modified from LeRocque and West [12].
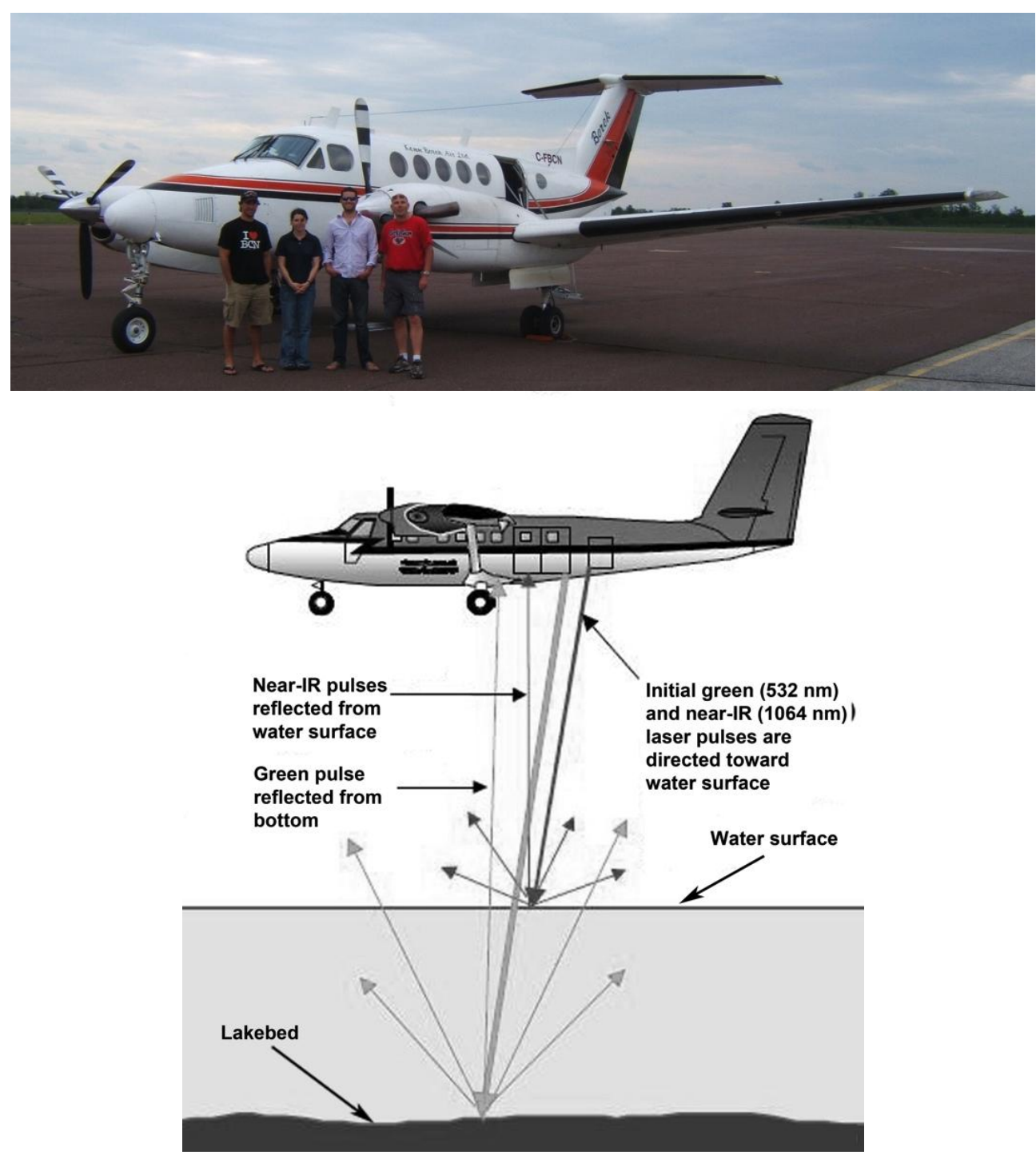
Grand (Big) Traverse Bay is an embayment along the southern coastline of Lake Superior, off the Keweenaw Peninsula (Figures 2 and 3). Between 1850 and 1929, the Keweenaw district was the second largest producer of copper in the world [13]. During that interval, 140 mines worked central deposits and over 40 mills processed stamp rock (Figure 2). In total, 4.8 million metric tons of copper were smelted from native copper deposits by 1968. The concentration of copper in the parent rock averaged between $0.5 \%$ and $6.1 \%$ of the total mass, producing vast amounts of tailings as a by-product of giant steam-driven stamps [14]. The stamps crushed the amygdaloid and conglomerate ores, and mills sluiced copper-rich stamp tailings into rivers and waterways. Between 1865 and 1968, approximately 360 million metric tons (Mt) of stamp sands were discharged from native copper stamp mills into interior waterways and along Lake Superior shorelines, including 64 Mt directly into Lake Superior $[8,9,15]$.

Figure 2. Native copper and silver mine era locations along the Keweenaw Peninsula, Upper Peninsula, of Michigan. The amount of tailings discharged (Mt, million metric tons) from larger, coastline "stamp" mills (1895-1947) are shown. The locations of mines (circles) and mills (hollow triangles) are plotted along the Portage Lake Volcanic Series and on the coast (modified from Kerfoot et al., [9]).

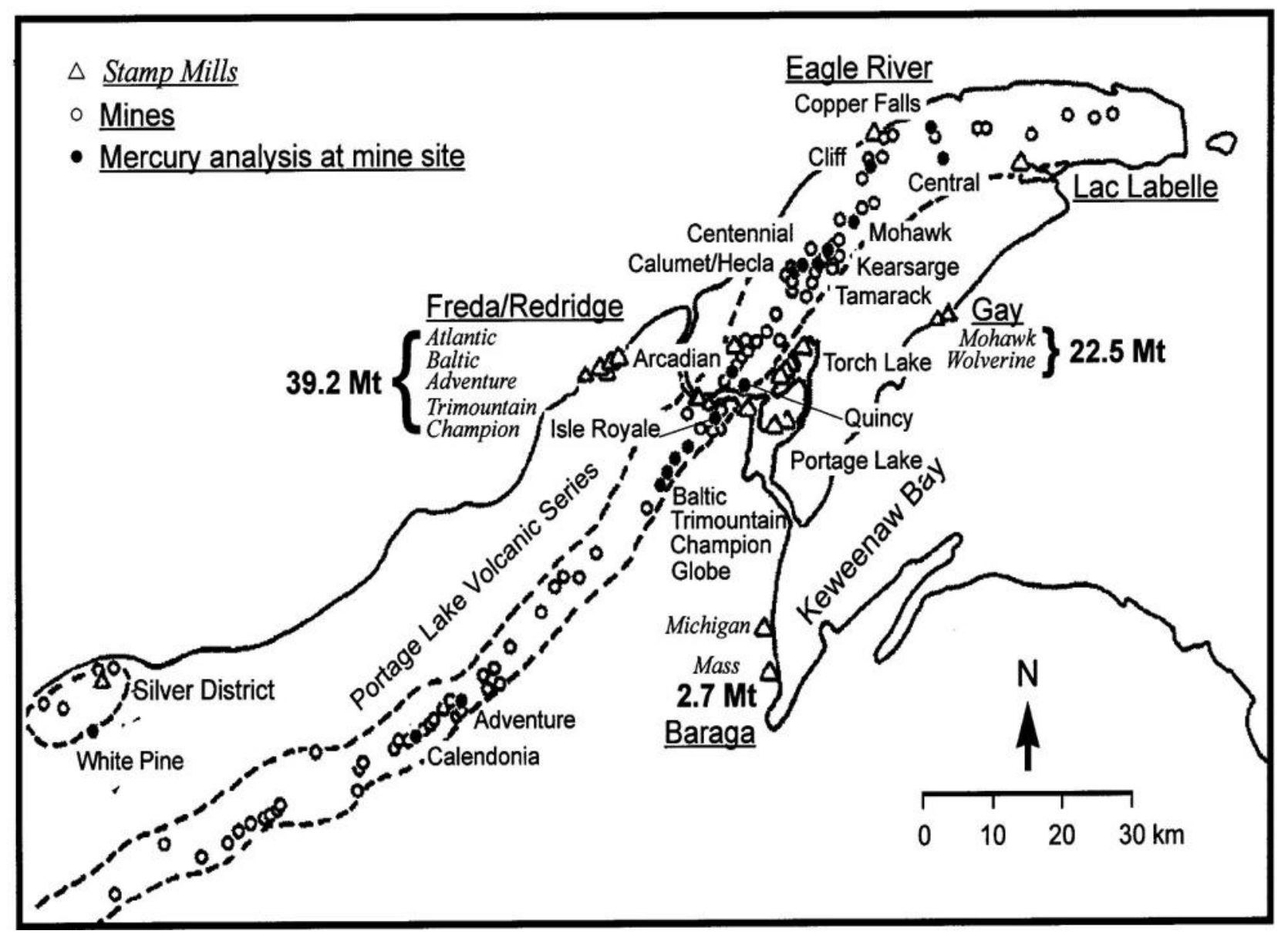

Large volumes of water were necessary for tailing processing at stamp mills. The success at inland sites required the local damning of rivers, as the milling process required water to discharge large volumes of stamp sands [9]. In the late 1890s, larger steam-driven mills opened on the shores of the largest inland lakes (Torch Lake, Portage Lake) and along the coast (Figure 2). On the western 
shoreline from Freda to Redridge, five mills (Adventure, Atlantic, Baltic, Champion and Trimountain) were built. The five mills opened during 1895-1902 and closed during 1908-1947, discharging a total of $39.2 \mathrm{Mt}$ of stamp sands. The construction of the eastern coastline operations was nearly synchronous, as the Mass (1902), Mohawk (1901) and Wolverine (1903) mills opened off Keweenaw Bay within three years of each other, yet closed earlier, between 1919 and 1932. The two large mills (Mohawk and Wolverine) at Gay were adjacent operations with a single superintendent, sluicing a combined 22.7 Mt onto one large coastline pile [3,8].

Figure 3. Geographic location of Grand (Big) Traverse Bay on the Keweenaw Peninsula jutting into Lake Superior. Landmarks include the position of the original tailing pile off Gay (the dashed boundary shows the 1938 extent), the Coal Dock, the Traverse River Seawall and the narrow natural white sand beach. The white dashed line outlines the 1938 boundaries of the stamp sand. The boundary of Buffalo Reef is superimposed over offshore waters. Before mining, erosion dominated along the northeastern coastal shelf region, whereas historical deposition dominated the southwestern shoreline (Nipissing beach ridges, natural white beach). Modern-day currents are predominantly southwestward.

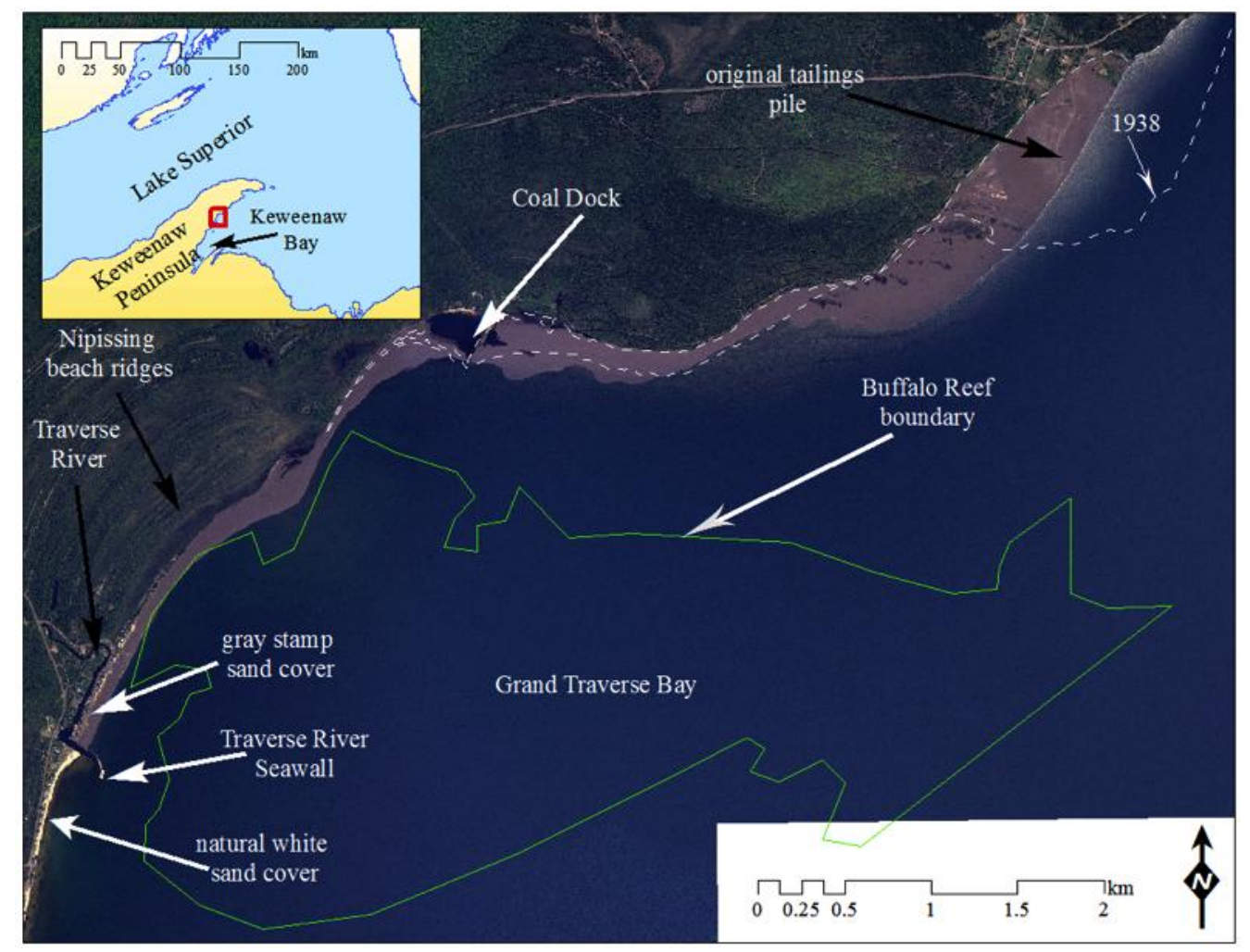

Here, we utilize LiDAR and MSS imagery to investigate the spread of tailings from a pile deposited in Grand (Big) Traverse Bay, near Gay (Figures 3 and 4). The native copper $(\mathrm{Cu})$ processed at Gay came from basalt lava flows (amygdule deposits; [16]). Stamp sands contained two fractions: (1) a coarse fraction (sand) with a specific gravity around 2.9; and (2) a fine silt-clay fraction, produced during the stamping and grinding of ore (the so-called "slime clays", [14]). Grain sizes on the original pile were angular, approximately log-normally distributed, with modal sizes ranging between 0.3 and $3.4 \mathrm{~mm}[17,18]$. The silt-clay ("slime clay") fraction from above-water portions of the 
coastal stamp sand piles averaged about 5\%-15\% of total mass [17]. The fine silt-clay fraction winnows out during wave erosion and disperses far across the coastal shelf, accounting for contamination in deep-water fine sediments (i.e., the metal-rich "halo" around the peninsula).

Figure 4. Stamp sands erode from the enormous tailing pile at (Above) Gay and over-top the (Below) Traverse River Seawall, spilling into the Traverse River channel.

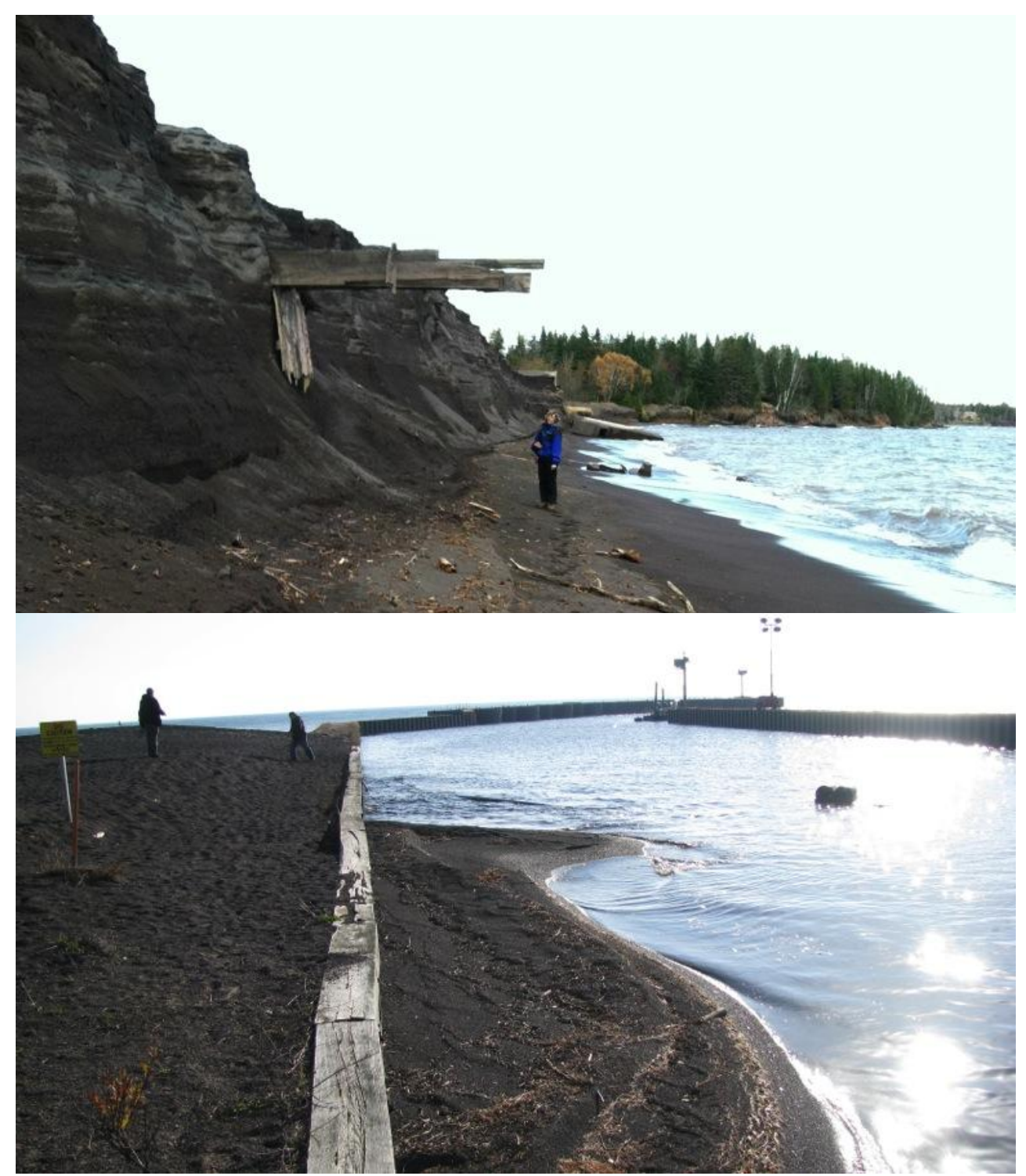

Both coarse and fine fractions contain severely enriched $\mathrm{Cu}$ at toxic levels for aquatic systems and a secondary suite of metals ( $\mathrm{Ag}, \mathrm{As}, \mathrm{Cd}, \mathrm{Co}, \mathrm{Cr}, \mathrm{Hg}, \mathrm{Mn}, \mathrm{Ni}, \mathrm{Pb}$ and $\mathrm{Zn}$ ) that often exceed aquatic probable effect levels $[19,20]$. Slime clay fractions $(<1 \mu \mathrm{m})$ tend to be enriched in metals higher than coarse fractions ( $\mathrm{Cu} 2.8 \mathrm{X}, \mathrm{Zn} 3.4 \mathrm{X}$, As 1.3X), due to a higher particle surface:volume ratio plus an absorbing crust of Fe and Mg [21]. Recent sampling studies by the Michigan Department of Environmental Quality (MDEQ) on the original Gay tailing pile found $\mathrm{Cu}$ concentrations of $1,500-13,000 \mu \mathrm{g} \cdot \mathrm{g}^{-1}$ (mean $\left.2,863 \mu \mathrm{g} \cdot \mathrm{g}^{-1} ; N=274\right)$ and slightly lower, $710-5,300 \mu \mathrm{g} \cdot \mathrm{g}^{-1}$ (mean $\left.=1,443 \mu \mathrm{g} \cdot \mathrm{g}^{-1} ; N=24\right)$, for the southern redeposited sands [20]. Metals in the secondary suite at the main Gay pile contain concentrations of: Ag 0.4-7.7 $\mu \mathrm{g} \cdot \mathrm{g}^{-1}$ (mean 1.8), As 1.0-15.5 $\mu \mathrm{g} \cdot \mathrm{g}^{-1}$ (mean 1.5), Cr 18-52 $\mu \mathrm{g} \cdot \mathrm{g}^{-1}$ 
(mean 28.8), Co 16-36 $\mu \mathrm{g} \cdot \mathrm{g}^{-1}$ (mean 22.9), $\mathrm{Hg} 0.06-0.11 \mu \mathrm{g} \cdot \mathrm{g}^{-1}$ (mean 0.10), Ni 20-48 $\mu \mathrm{g} \cdot \mathrm{g}^{-1}$ (mean 31), Pb 5.1-6.1 $\mu \mathrm{g} \cdot \mathrm{g}^{-1}$ (mean 2.6) and Zn 48-120 $\mu \mathrm{g} \cdot \mathrm{g}^{-1}$ (mean 74.7; [20]).

Figure 5. 2010 LiDAR-derived bathymetry of Grand Traverse Bay, showing the positions of the original Gay tailings pile, above-water (deep blue region) stamp sands along the beach stretch from the pile to the Coal Dock and southwestward to the Traverse River seawall and the central Buffalo Reef area. The "trough" region, an old riverbed, is in the center. To the northeast, note the underwater stamp sand bars moving across bedrock (Jacobsville Sandstone) to deposit in the "trough". To the southwest, natural sands and silts move out of the bay across the bottom into Lake Superior. Red horizontal contour lines are at 5-m depth intervals. ROV and side-scan sonar sites (1-5) are indicated in red.

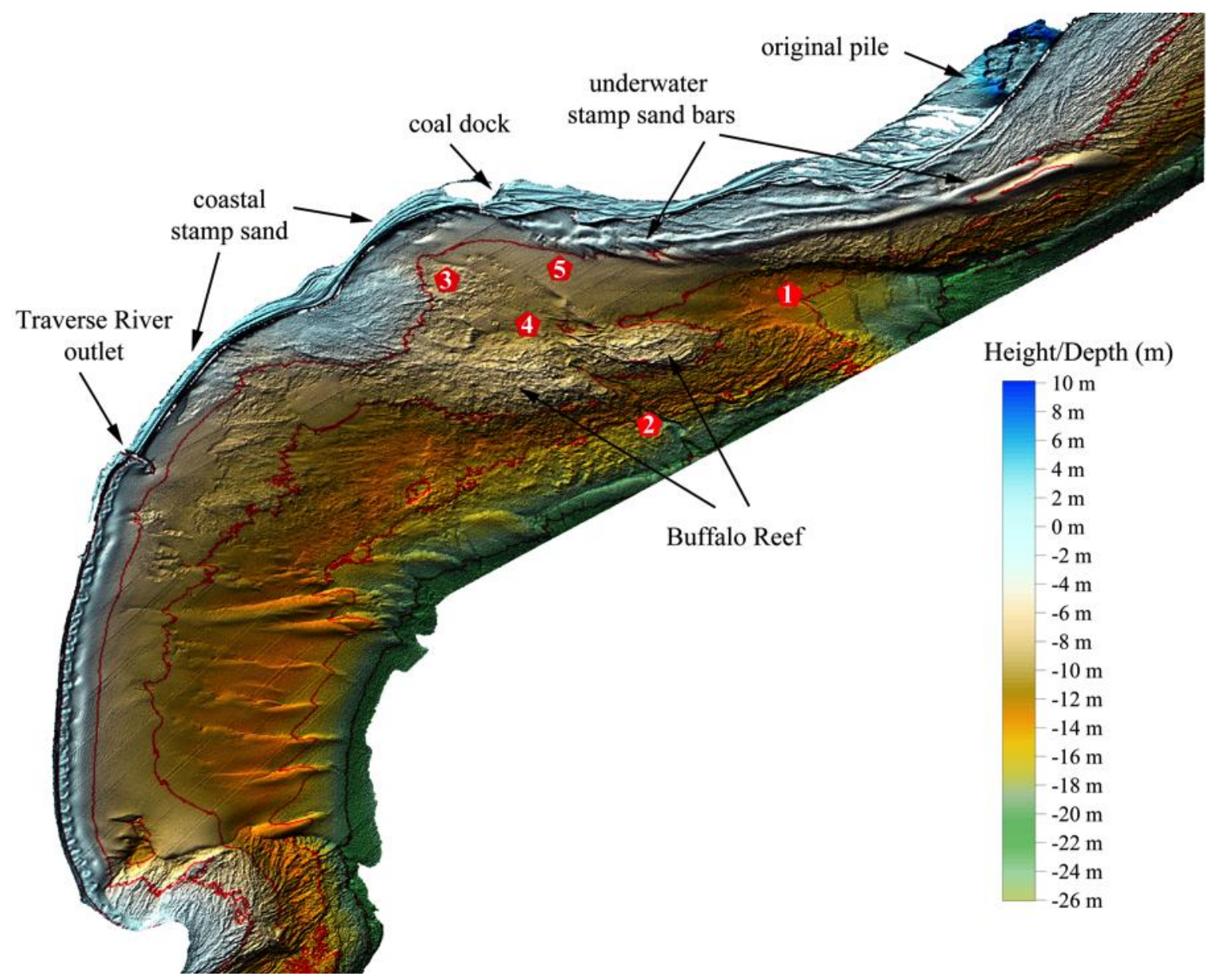

The movement of tailings in the coastal environment is important, for the migrating tailings in Grand (Big) Traverse Bay threaten important fish breeding grounds and rivers (Figures 4 and 5). Buffalo Reef (Figure 5) is recognized in the Atlas of the Spawning and Nursery Areas of the Great Lakes, Volume 2 [22]. The Great Lakes Indian Fish and Wildlife Commission (GLIFWC) conducted fisheries assessments on the reef between 1986 and 2002, documenting that it is an important spawning reef for lake trout (Salvelinus namaycush) and whitefish (Coregonus clupeaformis) [23]. Stamp sand movement is of great concern to the Keweenaw Bay tribal council, as both Michigan and Wisconsin tribal members maintain a commercial lake trout and whitefish fishery in Keweenaw Bay. The harvest of these fish is an important cultural and economic activity, as GLIFWC helps tribal 
members promote and market the health benefits of traditional foods [24]. The impairment of reef habitat could lead to a decline in important fish species, infringement upon federally guaranteed treaty reserved rights and negatively affect the health of the tribal and recreational fisheries population that consumes these resources. The transgression of drifting stamp sands into the cobble fields that comprise Buffalo Reef is not conducive to the normal hatching of fish eggs, for the sands may fill crevices or be toxic to eggs and newly hatched larvae. Moreover, the high copper concentrations in the sand may severely disturb other food web components, e.g., benthic communities of invertebrates and periphyton on substrates, food web components important to the rearing of lake whitefish in the bay.

\section{Methods and Materials}

\subsection{CHARTS Overflights and Mass Calculations}

Most of the airborne coastal mapping and charting data was collected using the CHARTS system [25]. CHARTS is a NAVOCEANO owned asset shared with the US Army Corps of Engineers (USACE [26,27]), which includes an Optech SHOALS 3000T20 with a 3-kHz bathymetric full waveform LiDAR (a green laser in the $532 \mathrm{~nm}$ wavelength) and a 20-kHz topographic discrete return LiDAR (near-infrared laser in the 1,064 $\mathrm{nm}$ wavelength), measuring land elevations with high resolution and accuracy (1-m spot spacing, $\pm 15 \mathrm{~cm}$ elevation accuracy), as well as water depths in areas of relatively clear water, or two to three times the Secchi depth $(5-\mathrm{m}$ spot spacing, $\pm 30 \mathrm{~cm}$ elevation accuracy [28]). The system also includes an Itres Compact Airborne Spectrographic Imager (CASI)-1500 for hyperspectral imaging, in which many narrow, contiguous spectral bands are measured across the electromagnetic spectrum [29]. The CASI hyperspectral scanner was configured to acquire data over eight bands uniformly spaced between 374 and 1,050 nm, including five visible wavelengths (nominal bandwidth of $84 \mathrm{~nm}$ ). For distinguishing sediment types, our main focus was on the green and red portion of the visible spectrum $(495-750 \mathrm{~nm})$. The delineation of the land-water boundary was best when using near-infrared bands.

Initial USACE CHARTS surveys were made in spring, 2008, and summer, 2011, in partnership with Mark Graves and Bruce Sabol, U.S. Army Engineer Research and Development Center-Environmental Laboratory (ERDC-EL), Vicksburg, Mississippi. The CHARTS surveys were flown over Grand (Big) Traverse Bay, with concurrent ship-based measurements using Michigan Tech University's (MTU) 10.4-m R/V Agassiz and $6.7 \mathrm{~m} \mathrm{R} / \mathrm{V}$ Polar. The surveys were accomplished with the second-generation CHARTS system operated from a fixed-wing King Air Beechcraft 200 aircraft (Figure 1). In general, the surveys included bathymetric and topographic LiDAR, collected simultaneously with aerial and hyperspectral imagery (CASI). A simple glint-removal algorithm was applied to the 2008 CASI overflight bands to correct for sun glint artifacts [30]. Because of sun glint difficulties, we obtained three-band MSS data from another aerial overflight (2009 USDA), taken during calmer conditions, to complement the 2008 CASI set. We also used the NOAA (National Oceanic and Atmospheric Administration) 2010 Great Lakes Restoration Initiative (GLRI) bathymetric LiDAR data in our analysis, where the data were collected in CHARTS format by the Fugro LADS Mk II system. ENVI 4.7 was used for the entire image processing procedure (Figure 6). The strips were mosaicked and re-projected. The original coordinate system was Geographical 
Lat/Long, yet for further distance, aerial and volume calculations, the data were re-projected to a Universal Transverse Mercator $($ UTM; projection = WGS84, zone = 16) coordinate system.

Figure 6. Flow chart for LiDAR, multispectral scanning (MSS) and aerial photography procedures used to calculate mass erosion and deposition and to classify substrates (black = primary data; red $=$ method/tool/procedure; orange = software used; green $=$ products $)$. NAIP, National Agriculture Imagery Program;

Bottom substrate classification

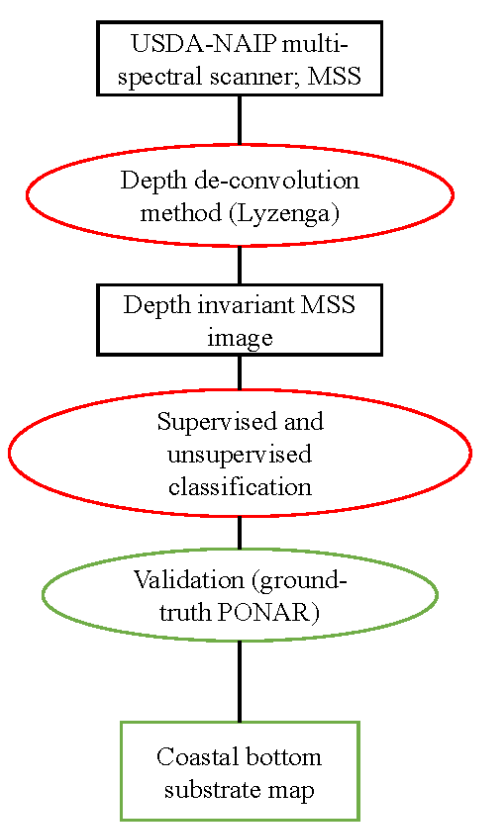

Mass/Volume and Erosion

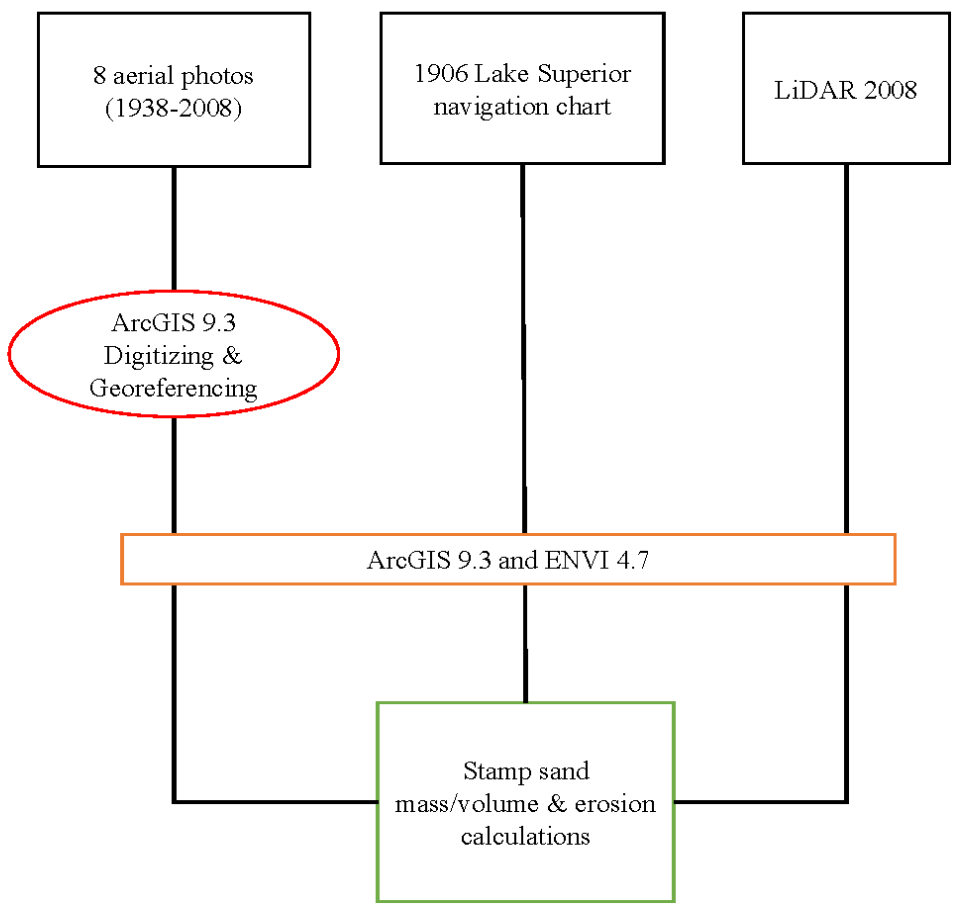

The advantage of multiple-year overflights is that the mosaicked images will allow for estimates of underwater stamp sand bar volume, mass and movement (via difference calculations between different dates; see [31] for a preliminary example). For a check on the accuracy of bathymetric measurements, the LiDAR-derived depths are cross-compared with each other and with georegistered NWRI (National Water Resources Institute) SONAR-derived depths and sediment classification maps [32]. The SONAR and LiDAR datasets were independently derived and, therefore, very useful for cross-calibration and change detection. Statistical software packages (SYSTAT, OriginPro) were used for determining spatial cross-correlations. In initial comparisons, the resulting regression matches between the NWRI bathymetry and 2008 LiDAR-derived bathymetry for Grand (Big) Traverse Bay were very similar $\left(R^{2}=0.98 ;[3]\right)$.

Using CHARTS LiDAR data along with eight aerial photos from 1938 to 2010, we reconstructed the 1938 Gay stamp sand pile volume and, with some reasonable assumptions, calculated the shoreline erosion rate of the pile between 1938 and 2010 (Figure 7; [3,31]). To measure the erosion of the tailing pile and the mass of sands washed into Lake Superior, three estimates were needed: (1) the area and volume of the pile above water level (available from the 2008 LiDAR); (2) the below-water volume, i.e., calculating the true depth of the stamp sand pile above lake bottom bedrock; and (3) the area of the 
pile lost through time (erosion at the shoreline face, estimated from aerial photos, essentially treated as vertical slices across the pile.

Figure 7. Aerial photo and LiDAR-derived estimates of erosion from the primary Gay tailing pile (black dots) through time and the corresponding accumulation of redeposited stamp sand on beaches south of the pile (red dots). Mass is in million metric tons (Mt), and 95\% C.L. around regressions are indicated by green bands. The erosion of the pile closely fits an exponential decline function, whereas accumulation on the beach closely fits a linear increase function.

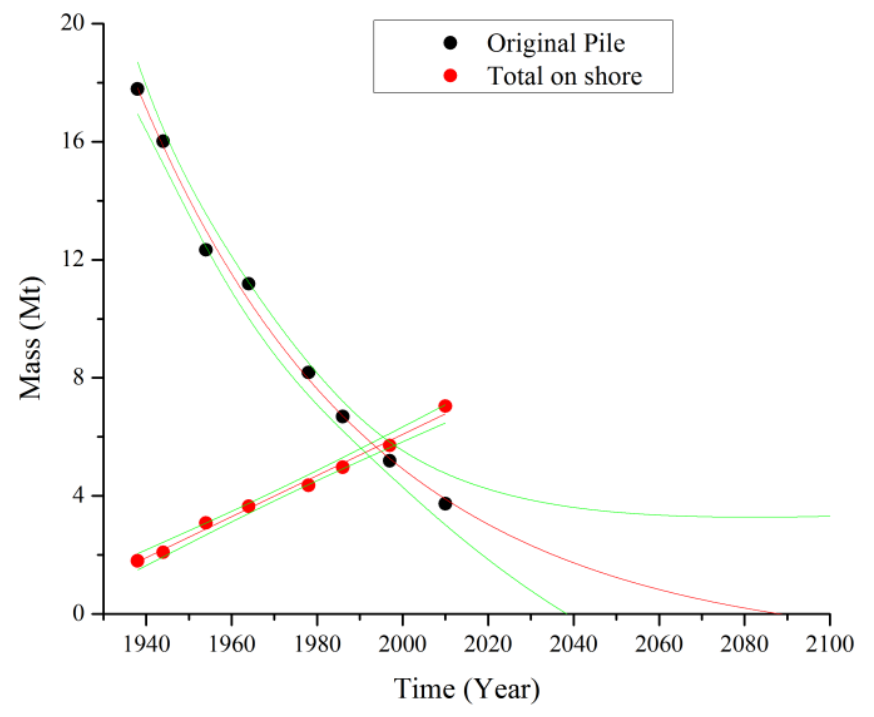

The original boundaries of the Gay tailings pile were determined from a georegistered 1938 aerial photograph of the region. ArcGIS 9.3 (ESRI) was used to digitize this aerial photo [33]. Strong prevailing currents [34,35] (National Oceanic and Atmospheric Administration Great Lakes Environmental Research Laboratory Now-cast Wind Model (2010)) transported stamp sand particles southwestward, covering northern natural Jacobsville Sandstone outcrops and southern white beach sands. Eight other aerial photos, taken between 1944 and 2010, provided subsequent shoreline edge changes on the original tailings pile and estimates of redeposition along southern beaches, both quantified with ArcGIS and ENVI (Figure 6, Table 1 [33]). The photos allowed the mapping of the original pile's changing boundaries, to which we fit polygons [3].

To estimate below-water volume, the pile was separated into two regions. One region was the portion of the pile eroded to bedrock, which allowed LiDAR-derived estimates of past bottom contours under the original pile, whereas the second portion was the remaining part covered by stamp sand. In the first portion (eroded area), we assumed a fairly constant yearly water level (183.4 m; Detroit District Corps) to estimate the underwater volume of the pile. To estimate the depth of the stamp sand in the second region, currently covered by stamp sand, we extrapolated the slope change of bedrock from the LiDAR bathymetric map adjacent to the pile to extend under the pile. The result of the linear slope analysis produced an average depth below the lake level of about $2 \mathrm{~m}$ for the currently covered portion. 
Table 1. GIS applications to Grand Traverse Bay project.

\begin{tabular}{|c|c|}
\hline GIS Software & Task \\
\hline ENVI 4.7 & $\begin{array}{l}\text { Resampled } 2-\mathrm{m}^{2} \text { LiDAR data DEM into } 3-\mathrm{m}^{2} \text { resolution bathymetry maps; the locations } \\
\text { and orientation of the laser source was determined by GPS and internal measurement } \\
\text { units; } 2008 \text { LiDAR DEM provided height measurements of the } 2008 \text { pile. }\end{array}$ \\
\hline ArcGIS 9.3 & Digitized aerial photographs and georeferencing. \\
\hline ArcGIS, ENVI & $\begin{array}{l}\text { Quantified shoreline edge changes on the original tailing pile; Estimated redeposition } \\
\text { along southern beaches; mapped the original pile's changing boundaries, to which we fit } \\
\text { polygons; used the remains of surface sluiceways on the pile to estimate the heights of the } \\
\text { material. In volume calculations utilized an area of } 9 \mathrm{~m}^{2} \text {; Bottom contours of } 1906 \text { (Lake } \\
\text { Superior Coast Chart 4) were superimposed on } 2008 \mathrm{LiDAR} \text { above-ground aerial map of } \\
\text { the shoreline stamp sands to calculate the above and below volume of stamp sands. }\end{array}$ \\
\hline $\begin{array}{l}\text { ERDAS } \\
\text { IMAGINE }\end{array}$ & $\begin{array}{l}\text { The MSS substrate classification map required three components: (1) finished } 2008 \\
\text { LiDAR bathymetry map; (2) finished MSS mosaic, stitched together from various } \\
\text { overflight tracks; (3) Lyzenga calculations to create the depth-independent bottom } \\
\text { reflectance image. Because of glint problems, three-band MSS data (band 2, } 490 \mathrm{~nm} \text { blue; } \\
\text { band } 3,581 \mathrm{~nm} \text {, green) from NAIP } 2009 \text { flyover were utilized, taken under calmer } \\
\text { conditions. MSS images were projected to the Universal Transverse Mercator Zone } 16 \\
\text { coordinate system, translating the data from MSS images; utilized bottom type attributes } \\
\text { (albedo, color, depth-corrected radiance) to construct sediment classification. }\end{array}$ \\
\hline
\end{tabular}

To estimate the volume lost above water (i.e., exposed shoreline component), we also needed to determine the elevation of the stamp sand pile removed by shoreline erosion. Again, we considered the same two regions: current pile and the portion of the pile that was lost. The high resolution 2008 LiDAR DEM provided the height measurement of the 2008 pile. Past pile elevations were reconstructed by extending the height of known existing landmarks (the ends of preserved sluiceways) across the aerial photos to estimate local depth. A projected extension of the sluiceways was used to estimate the height of eroded portions and past aerial photos to estimate area dimensions. The underwater volume was added based on the estimated depth to bedrock.

The reconstructed pile was first used to calculate the volume and mass of stamp sand in 1938. The procedures employed a polygon spatial resolution of $3 \mathrm{~m}$ and an area of $9 \mathrm{~m}^{2}$. Multiplying area by depth gave an estimate of the volume of stamp sand for each polygon. Integration provided an estimate of total volume in cubic meters. An average of Colin's (internal report 2009; accessible from the US Department of Agriculture's Natural Resource Conservation Service (NRCS)) Web Soil Survey values was used to assign mass. The moist bulk density of the Gay Stamp Sands soil was estimated as being between 1.35 and 1.65 grams per cubic centimeter $\left(\mathrm{g} \cdot \mathrm{cm}^{-3}\right)$ or $1,350 \mathrm{~kg} \cdot \mathrm{m}^{-3}$ to $1,650 \mathrm{~kg} \cdot \mathrm{m}^{-3}$. We chose the mean bulk density value of 1.65 grams per cubic centimeter and calculated the mass for each eroded slice. An exponential decay equation was fit to the mean erosion curve, giving an intercept estimate of the date when the pile would be gone (i.e., zero mass). For our analysis (Figure 7), erosion values since 2008 were updated to the present. 


\subsection{Passive Color (CHARTS Hyperspectral and MSS) Substrate Classifications around Buffalo Reef}

The interpretation of 2008-2013 MSS patterns was aided by stamp sand and substrate differences in spectral reflectance [3]. The grey-to-black stamp sands (crushed basalt) on the beach have a relatively low albedo, whereas the natural white beach sands (derived from Jacobsville Sandstone) have a relatively high albedo. Detailed spectral reflectance differences suggest the good depth resolution of primary substrate types along the coastal margins. Spectral signature procedures follow [36], using an Analytical Spectral Devices (ASD), Inc., FieldSpec Pro (model FSP350-2500PJ) and were published in Kerfoot et al. [3]. At present, spectral reflectance profiles are available for: (1) stamp sands from the primary discharge pile; (2) wave-reworked stamp sands; (3) native beach sands, derived from Jacobsville Sandstone; (4) Jacobsville Sandstone; and (5) various mixed stamp sands and natural sands. Additional MSS images of Grand Traverse Bay were retrieved from the National Agriculture Imagery Program (NAIP) multiresolution seamless image databank (Figure 6, years 2005 and 2009). To quantify downwelling and upwelling spectral irradiance in deeper waters, bottom reflectance was quantified using Green's Satlantic OC P1000 Optical Profiling Radiometer.

The Satlantic work provides attenuation coefficients for downwelling and upwelling spectral bands. Other critical additional variables were surface irradiance energy and coefficients for depth-dependent spectral transmission. From these two parameters, we calculated the maximum water depth that light of different wavelengths could penetrate, according to the simple formula: $I_{z}=I_{o} e^{-\epsilon l z}$. However, for MSS resolution, ambient light must reflect off the bottom surface and return a signal to the surface plane, hence the importance of the Satlantic upwelling irradiance measurements. The ArcGIS software package (Version 9.3) was used to create a depth-dependent mask that was superimposed upon the MSS data to check the ability to resolve substrate color contrasts (Table 1 [33]). We used Lyzenga's [37] method for depth-correcting radiance. Lyzenga provided a procedure for handling depth-dependent reflectance effects in MSS imagery, allowing the production of a depth-independent bottom reflectance map. Ratio-based algorithms determined the relation between different spectral bands over the same bottom type. The polygons are then classified (using a combination of supervised and unsupervised classification methods) by substrate type (Figure 6). By applying this method, we were able to separate different bottom types based on their reflectance. The MSS images were projected to UTM zone 16 coordinate system and pixel values converted to actual spectral reflectance values (watts $/ \mathrm{m}^{2}$ ) for comparison with Satlantic data. ArcGIS or ERDAS IMAGIN was used to translate data from MSS images (Table 1; two datasets, 2008 and 2011, CASI; 2009 and 2010, USDA NAIP overflights, using a Leica ADS40 sensor).

For a check on the accuracy of substrate classifications, the MSS classifications are cross-compared with each other and with georegistered NWRI (National Water Resources Institute) substrate classifications for Grand Traverse Bay [32]. The Biberhofer and Prokopec [32] substrate classification was based primarily on sonar transects supplemented by occasional Shipek sediment samples and underwater video camera images. 


\subsection{Underwater Video (ROV), Side-Scan Sonar, Ponar Substrate Sampling and Benthic}

\section{Faunal Characterization}

Connecting biological effects with stamp sand encroachment requires higher resolution imaging than what comes from LiDAR and MSS, plus the treatment of several direct and indirect effects, all of which appear deleterious. For example, once they hatch, lake whitefish are known to disperse from the cobble fields of Buffalo Reef to the southern white beach region (fry rearing area), where they feed on benthic organisms. Using beach seine samples, Bill Mattes (personal communication) from GLIFWC documented abundant lake whitefish fry along the white sandy beach near-shore region, but none along the stamp sand beach region. Whitefish could be absent in regions covered by stamp sands because: (1) stamp sand fills in crevices in the boulder/cobble field, destroying hiding places and boundary conditions; (2) copper kills benthic diatoms and invertebrates (i.e., eliminating consumers and/or their resources, the lower two food chain levels); or (3) dissolved copper directly harms fish fry.

For insight into these options and to provide ground-truth (spot checks) for mapping stamp sand encroachment, we used an ROV (VideoRay Pro II) with mounted underwater cameras (MarCum VS620 Underwater Viewing System; up-close resolution of millimeters) off the R/V Agassiz and R/V Polar in 2012 and 2013. Preliminary surveys are available [31] (https://sites.google.com/site/keweenawbuffaloreef/). These dives verified the utility of cameras mounted on ROV's for identifying the variety of substrates in Grand (Big) Traverse Bay. The ROV studies allowed us to conduct coordinated underwater video, substrate ground-truth sampling (Ponar) and preliminary area surveys (NOAA R/V Storm). NOAA R/V Storm studies utilized high resolution and digital side scan sonar (New EdgeTech, high resolution side scan sonar, dual frequency 600/1,600 $\mathrm{kHz}$ with the full 3D mapping system; resolution $0.6 \mathrm{~cm}$ ). Underwater photography and sediment samples helped classify the nature of stamp sand encroachment onto Buffalo Reef cobble fields, clarified impacts on benthic communities and clarified the potential mechanisms of fish inhibition. Sediment samples were photographed and supplemented by underwater video images of sediment surfaces, taken by the MarCum VS620. Ponar $\left(0.046 \mathrm{~m}^{2}\right)$ sediment samples were taken in duplicate, washed and sieved $(500 \mu \mathrm{m})$ onboard in a sediment elutriator and preserved in $10 \%$ formaldehyde for later taxonomic analysis. Grain analysis allowed us to determine the percent of the stamp sand composition of the sediments.

\section{Results}

\subsection{Features of Grand (Big) Traverse Bay}

In Figure 5, the 2010 LiDAR-resolved bathymetry reveals the critical coastline features of Grand (Big) Traverse Bay and the central location of Buffalo Reef. The coastal shelf is flanked by two rivers: the Tobacco River northeast of the original tailing pile and the Traverse River in the southwestern portion of the bay. Both rivers discharge highly colored humic waters that dissipate quickly. East of Buffalo Reef, the "trough" appears to be an ancient riverbed located between the existing two rivers, stretching $2 \mathrm{~km}$, scoured to a depth of 2-3 m into Jacobsville Sandstone bedrock. Underwater regions southwest of the original tailing pile reveal stamp sand bars moving over Jacobsville Sandstone bedrock towards the "trough". The bars contain substantial mass and reach the "trough" at mid-level below the Coal Dock. ERDC-EL at Vicksburg estimated that the "trough" has a 
surface area of $c a \cdot 1,275,400 \mathrm{~m}^{2}\left(1.3 \mathrm{~km}^{2}\right)$ and a volume of 4,205,200 $\mathrm{m}^{3}$. However, because the upper reaches are covered by migrating stamp sands, these channel estimates are only approximate. The deeper, outer reaches of the "trough" appear to show cuts through bedrock, i.e., bedding planes of Jacobsville Sandstone, whereas the upper and middle reaches are filled with stamp sand or mixtures of stamp sands and natural sands.

Coastal processes at Grand (Big) Traverse Bay site are forced by a combination of natural factors that include waves and winds, alongshore currents, fluctuations of water level, varying bathymetric gradients and differences in substrates [3,38]. In a preliminary hydrodynamic modeling effort, Weston [38] characterized Keweenaw Bay in Lake Superior as a shallow-water, fetch-limited system. Along the shoreline, short-period, wind-driven waves seemed the principle factor moving stamp sands onto and down the beach. From the inspection of wave-rose data, the predominant waves came from headings of $90^{\circ}$ to approximately $155^{\circ}$. The Keweenaw Peninsula shelters the Gay site from wind-generated waves, with headings between $210^{\circ}$ and $360^{\circ}$. Prevailing currents along the eastern coastline of the Keweenaw Peninsula flow predominantly southwestward, parallel to isobaths $[35,39,40]$. Measurements by Sloss and Saylor [39] documented periodically strong $\left(1.0-5.0 \mathrm{~cm} \cdot \mathrm{s}^{-1}\right)$ summer and fall southwestward alongshore currents.

\subsection{Tailing Pile Erosion and Dispersal}

As wave erosion of the original Gay tailing pile proceeds, the coarse fraction is moved from the original deposition cone (Figure 4 top) southward as a sorted black sand lens mixing with or transgressing over Grand Traverse Bay white quartz beach sands (Figures 3 and 5; [3,38,41]). We found that redeposited stamp sands moved $7.4-8.1 \mathrm{~km}$ south from the Gay pile as black beach sands, extending to the northern face of the Traverse River Seawall. The stamp sands are now working their way around and over ("over-topping") the sea wall (Figure 4 bottom). MDEQ [20] samples offshore and immediately south of the Gay stamp sand pile found copper concentrations in bay sediments varying between 1,400 and $4,400 \mu \mathrm{g} \cdot \mathrm{g}^{-1}$ (mean $=3,020 \mu \mathrm{g} \cdot \mathrm{g}^{-1}, N=5$ ). That mean value is close to pure stamp sands, suggesting little admixture with natural beach sands or Tobacco River sediments near the original Gay tailings pile.

At the tailings pile site, 80 years of aerial photography allowed us to calculate an estimated erosion rate of $-7.8 \mathrm{~m} / \mathrm{yr}$ [3]). For comparison, Weston [38] estimated a value of $-7.2 \mathrm{~m} / \mathrm{yr}$ for shoreline regression at the tailing site, a similar value. South of the pile, the shoreline showed an alternating erosive and accretion pattern in response to the irregular bathymetric contours of the nearshore zone. The net shoreline change within the coast south of the Coal Dock region was $+0.5 \mathrm{~m} / \mathrm{yr}$, whereas the shoreline close to the Traverse River Seawall was experiencing an estimated accretion rate of $+2.2 \mathrm{~m} / \mathrm{yr}$.

Using the 1906 bathymetric map and 2008 LiDAR overflight to estimate bottom contours and eight aerial images to measure erosional slices across the pile through time, we estimated that mass erosion of the Gay tailing pile was greatest early in the record and has declined recently [3,31]. Log-transformed values indicate an excellent fit $\left(R^{2}=0.99\right)$ of mass erosion to a simple negative exponential decay model (Figure 7; Table 2). The regression fit to log-transformed data was used to predict: (1) the rate of erosion; and (2) the "zero" mass intercept date (ca. 2090, with a rather large 
$\pm 95 \%$ C.L. envelope). By that date, given the observed rates of erosion, we estimate that the primary tailing pile will be entirely gone.

Table 2. Regression values for (a) stamp sands deposition onto onshore beach locations and (b) erosion off the original pile.

\begin{tabular}{cccccc}
\hline Fit Type & Regression & Y-Intercept & Slope & $\boldsymbol{S E}$ & $\boldsymbol{R}^{\mathbf{2}}$ \\
\hline Linear & Deposition onto onshore & -133.15 & 0.07 & 0.002 & 0.99 \\
\hline
\end{tabular}

(a)

\begin{tabular}{cccccccccc}
\hline Fit Type & Source & Equation & $\mathbf{y}_{\mathbf{0}}$ & $\mathbf{A}_{\mathbf{1}}$ & $\mathbf{t}_{\mathbf{1}}$ & $\boldsymbol{R}^{\mathbf{2}}$ & $\begin{array}{c}\text { X- } \\
\text { Intercept }\end{array}$ & $\begin{array}{c}\text { Lower } \\
\text { Limit }\end{array}$ & $\begin{array}{c}\text { Upper } \\
\text { Limit }\end{array}$ \\
\hline \multirow{2}{*}{ Non-linear } & $\begin{array}{c}\text { original } \\
\text { pile mass }\end{array}$ & $\mathrm{y}=\mathrm{A}_{1} \cdot \mathrm{e}^{(-\mathrm{x} / \mathrm{t} 1)}+\mathrm{y}_{0}$ & -1.424 & $7.65 \times 10^{16}$ & 53.8197 & 0.99 & 2,073 & 2,042 & $>2,080$ \\
\hline
\end{tabular}

(b)

Using the series of four CHARTS images, the mass of deposited beach sands along various sections of the coast could also be estimated through time (Figure 7; Table 2). The entire mass of stamp sand deposited along the coastline was estimated as $7.0 \mathrm{Mt}$, about $30.8 \%$ of the original stamp sand mass discharged onto the tailing pile $(22.7 \mathrm{Mt})$. Given the LiDAR high resolution and the clear gouges left on the pile by the Road Commission, we could also estimate that winter road application and bed construction removed about $1.01 \mathrm{Mt}$ of the Gay, MI, pile total mass (4.4\%). By the difference, the remaining $11.1 \mathrm{Mt}(48.9 \%)$ has moved out into Grand Traverse Bay, spreading across the underwater substrates. Estimates of above-water shoreline beach cover ranged from $1.6 \mathrm{~km}^{2}$ [3,31] to $2.3 \mathrm{~km}^{2}$ [41]. The aerial underwater cover of stamp sands across Grand (Big) Traverse Bay was estimated from MSS as $5.1 \mathrm{~km}^{2}$ [3], although this estimate does not include cover below the bottom reflectance capability.

Figure 7 summarizes the long-term estimate of mass movement. At present, the mass of stamp sand in the original pile has diminished to the point where it is far less $(3.1-3.7 \mathrm{Mt})$ than the combined amount along the shoreline to the south of the pile $(7.0 \mathrm{Mt})$. The Coal Dock stretch (the pile to Coal Dock) is holding 4.5 Mt of stamp sand. Along the shoreline beach, accumulation over time in the original pile to the Coal Dock section (Section 2) appears to fit a simple linear function through time (slope $=0.035$, S.E. $=0.003 ; R^{2}=0.93$ ). The mass of stamp sand in the Coal Dock to Traverse River section $\left(2.6 \mathrm{Mt}\right.$ ) also shows an increasing simple linear trend (slope $=0.035$, S.E. $=0.001 ; R^{2}=0.99$ ). A combination of both accrual estimates gives a single line with double the slope (Table 2; slope $=0.07$, S.E. $=0.002 ; R^{2}=0.99$ ). If the accumulation of beach stamp sands at the Coal Dock section continues in a linear fashion, 52 years from now, there would be an additional accumulation of 1.8 Mt along the shoreline north of Buffalo Reef. That much accumulation would certainly place Buffalo Reef in great peril.

The deep migrating stamp sand bars move across the Jacobsville Sandstone coastal bedrock, then deposit into the mid-section of the "trough", creating a mound and a westward migrating wall (Figures 5 and 8). At present, the upper and middle reaches of the "trough" appear filled to the point that westward encroachment of stamp sands into Buffalo Reef has begun. Moreover, the recruitment of wave-sorted material from migrating coastal stamp sand beach deposits has already dispersed southward and westward into and through parts of the northern cobble field (Figures 5, 8-11). 
Figure 8. Enlargement of the 2010 LiDAR-derived mosaic documents stamp sands moving into the northern cobble/boulder fields of Buffalo Reef. Migrating stamp sand bars pour into the "trough", mounding up in the northern reaches of the trough before progressing northwestward onto Buffalo Reef. Red contour intervals are spaced at $5 \mathrm{~m}$.

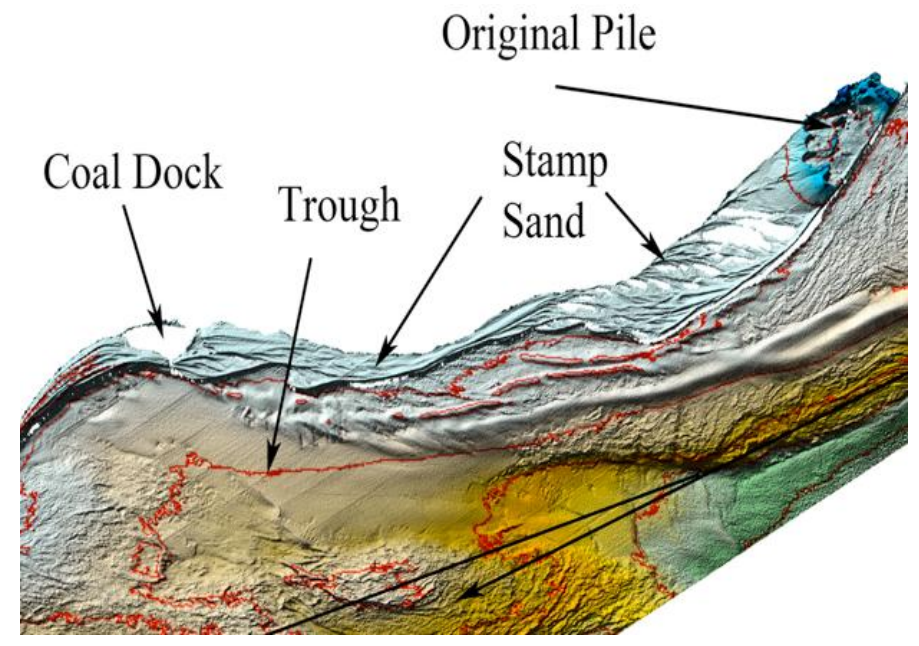

Figure 9. MSS-derived coastal substrate map, based on bottom color reflectance. Dots indicate Ponar and underwater camera ground-truth checks of substrate types (modified from Kerfoot et al. [3]). The boundaries of Buffalo Reef are superimposed upon the substrate map. Red regions indicate low reflectance areas where migrating stamp sands have encroached upon Buffalo Reef cobble and boulder fields.

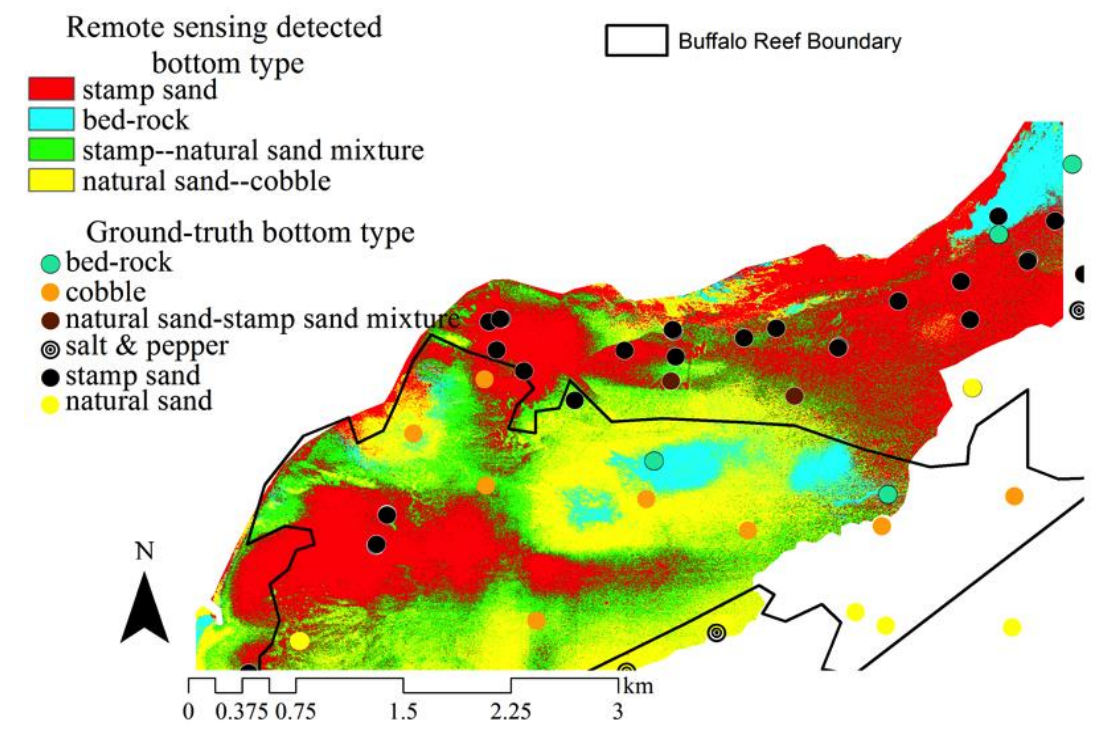

Along the shoreline, the "Coal Dock", a dock complex that received coal for Gay operations, may have served as a "groin" during the early erosion of the main pile (the dashed 1938 stamp sand margin in Figure 3). The dock also may have helped deflect shoreline migrating stamp sands into the upper reaches of the northern cobble field fringe around Buffalo Reef. Buffalo Reef boundaries include cobble-covered outlying and boulder-elevated regions on a Jacobsville Sandstone promontory of $\sim 3.1 \mathrm{~km}^{2}$, divided by a steep crevice (Figures 5 and 8). The reef has two lobes, a $2.0-\mathrm{km}^{2}$ plus a smaller, outer $1.1-\mathrm{km}^{2}$ portion. Northwest of Buffalo Reef, there is an underwater promontory that also 
may have helped divert migrating stamp sands. The promontory has a low region where migrating stamp sands have broken through and filled a depression to the west (Figure 9).

Figure 10. Side-oriented sonar image (Lowrance HDS7 from R/V Polar) of stamp sand falling into the "trough" (site 1 in Figure 5). (Left) The vertical scan of the $2.7 \mathrm{~m}$-high "trough" east wall. (Right) The lateral scan of the stamp sand moving over the east wall escarpment and cascading into the "trough". The dark central band in the horizontal image is the unrecorded track directly beneath the boat.

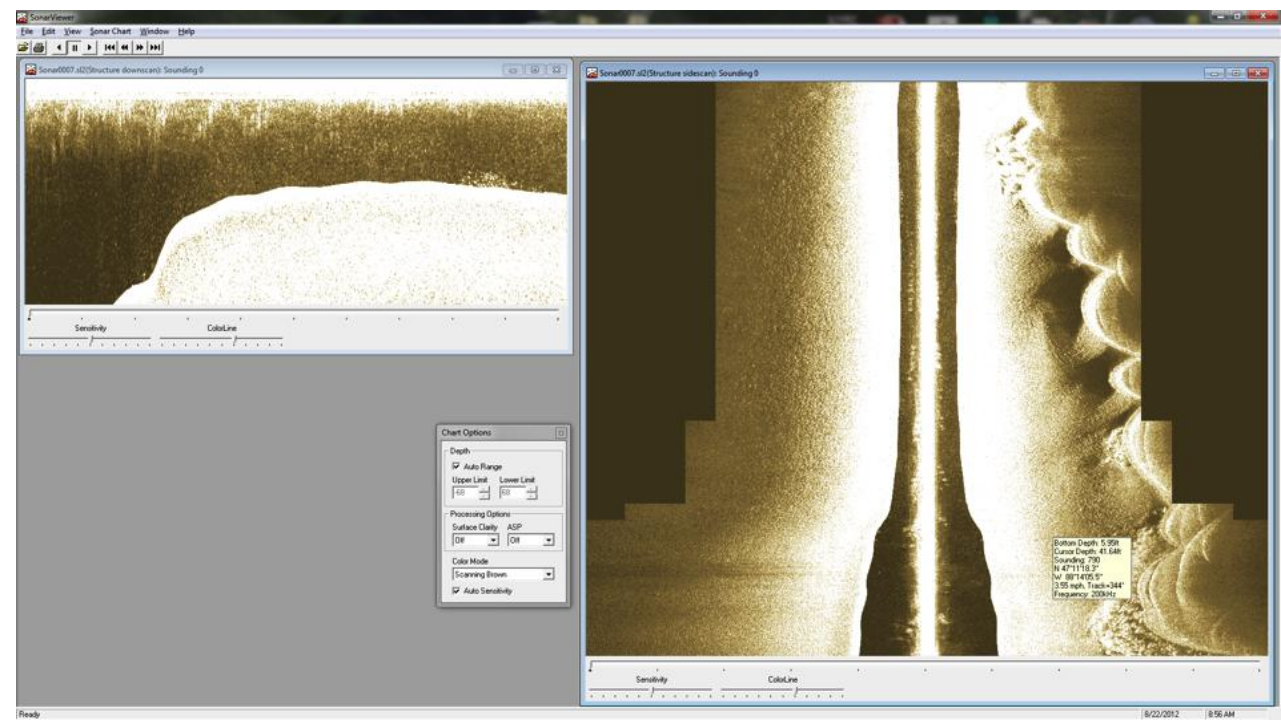

Figure 11. High-resolution side-scan image (New EdgeTech, HRSSS, 600/1,600 kHz from National Oceanic and Atmospheric Administration (NOAA) R/V Storm; $0.6 \mathrm{~cm}$ resolution) of stamp sands encroaching into Buffalo Reef cobble fields (site 2; Figure 5). Drifting stamp sands are on the left side of the image, whereas boulder fields are on the right side. Notice the ripples along the leading edge of the stamp sands and how the fine sand particles fill in crevices in the cobble/boulder field.

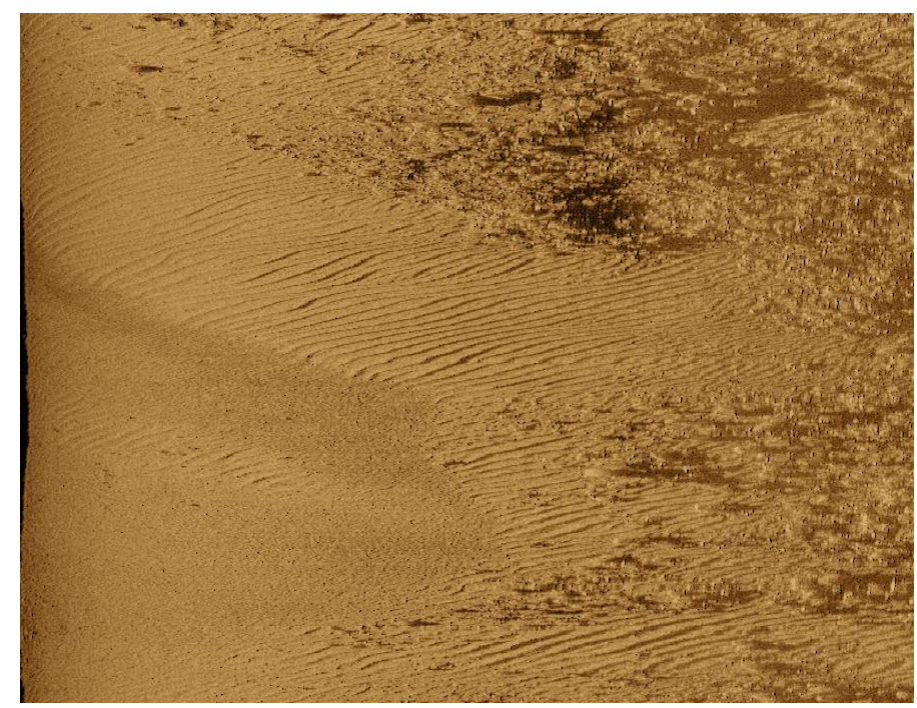


LiDAR-derived images from 2010 clearly show the mounding of stamp sands in the middle regions of the trough due to spilling from migrating stamp sand bars and a prominent wedge of stamp sands moving into cobble fields near the middle portion of Buffalo Reef (Figure 8). Underwater encroachment of stamp sands onto Buffalo Reef features two processes: (1) wave and current-driven drift and deposition of migrating underwater stamp sand material into the "trough" and into the middle reaches of the cobble field (Figures 9-11); plus (2) wave-driven sloughing of beach sands into the northern fringes of the cobble field. Multiple LiDAR images allow preliminary estimates of the migrating bar volume and movement rates [31], whereas sonar surveys in 2012-2013 with ROV-mounted cameras confirmed stamp sand spilling into the "trough" (Figure 10; Site 1 in Figure 5) and filling in edges of boulder fields (Figures 9-11; also, see [31]: https://sites.google.com/site/ keweenawbuffaloreef/).

The MSS (multi-spectral scanner) data from overflights are significantly different from LiDAR, because they are based on the passive spectral reflectance off the bottom substrates. Interpretation of MSS patterns is aided by stamp sand and substrate differences in spectral reflectance. The grey-to-black stamp sands (crushed basalt) on the beach have a relatively low albedo, whereas the natural white beach sands (derived from Jacobsville Sandstone) have a high albedo. Additional spectral reflectance differences suggest the good depth resolution of three primary substrate types along the coastal margins: stamp sands, natural beach sands and Jacobsville Sandstone (coastal rock outcrop).

MSS substrate classification showed that stamp sands had broken through a bathymetric low northwest of Buffalo Reef and spread westward across the bottom, now surrounding two-thirds of the reef and increasing the urgency for action (Figure 9; [3]). The total underwater surface area covered by stamp sands in the bay was estimated from MSS as $5.1 \mathrm{~km}^{2}$, whereas a corresponding $1.3 \mathrm{~km}^{2}$ of the beach area was covered by above-water stamp sands [3]. In Figure 9, there are depressions to the west of Buffalo Reef that are now filled with coarse stamp sand.

Side-scan sonar and ROV surveys reveal boulder field details and provide direct evidence for stamp sand encroachment (Figures 11 and 12). MSS and side-scan sonar studies are beginning to answer critical questions about the percentage of encroachment of stamp sands into the northern and middle reaches of Buffalo Reef boulder/cobble fields (Figure 9, site 4 in Figure 5). Cobble fields on Buffalo Reef (site 3 in Figure 5) are characterized by rounded lag boulders and cobbles covered by periphyton (Figure 12a). The coating makes the rocks seem uniform in color under underwater video imaging, but the heterogeneous nature of the rocks can be determined when the periphyton layer is scraped off. ROV dives are demonstrating that sands encroach upon gravel and cobble beds along the northern stretches of the reef (Figure 12b; site 4 in Figure 5).

\subsection{Biological Effects}

ROV studies document that underwater encroachment of stamp sand onto Buffalo Reef involves two separate processes: (1) wave and current-driven drift and deposition of stamp sands into cobble fields, filling up crevices and "drowning" the boulder field in a sea of stamp sand (Figures 11 and 12b); whereas the second process includes (2) the toxic effects of copper upon benthic organisms, including periphyton (diatoms and bacteria), invertebrates and fishes (Figure 13). Preliminary surveys in 2012 
and 2013 with ROV-mounted cameras documented stamp sands filling in edges of boulder fields with the border boulders losing periphyton films (Figure 12b).

Figure 12. (a) The remote operating vehicle (ROV)-mounted camera view of an undisturbed Buffalo Reef boulder/cobble field (site 4 in Figure 5). Cobbles and boulders are coated with a natural organic diatom and bacterial periphyton film. During spawning, fish eggs drop into the crevices between rocks. Most of the cobbles and boulders are rounded glacial lag erratics, sitting on top of, rather than originating from, the underlying Jacobsville Sandstone. (b) An ROV video of stamp sands (coming from the left; notice ripples) moving into the northern cobble field (to the right) of Buffalo Reef (site 3 in Figure 5). The stamp sands are both filling in crevices and killing periphyton communities on rocks along the leading edge of the encroachment zone. (c) An ROV clip of ripples in a stamp sand field encroaching onto Buffalo Reef's twin promontories. Notice the white flocculent organic material (dead periphyton), sloughing off the boulder field, lying in depressions between ripples (site 5 in Figure 5).

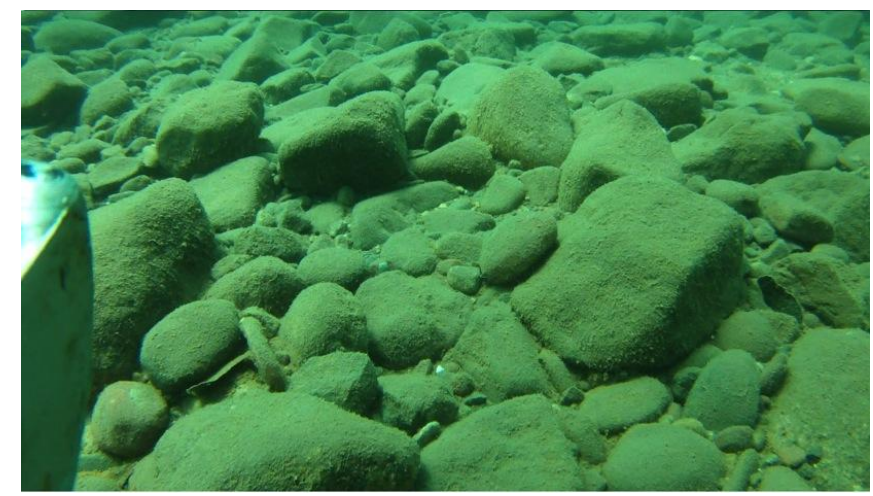

(a)

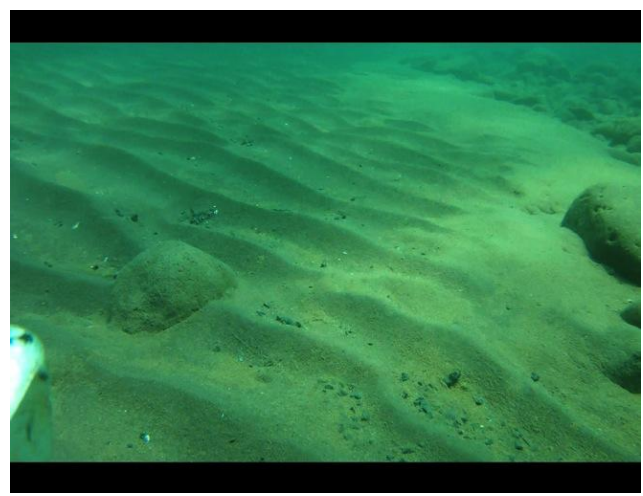

(b)

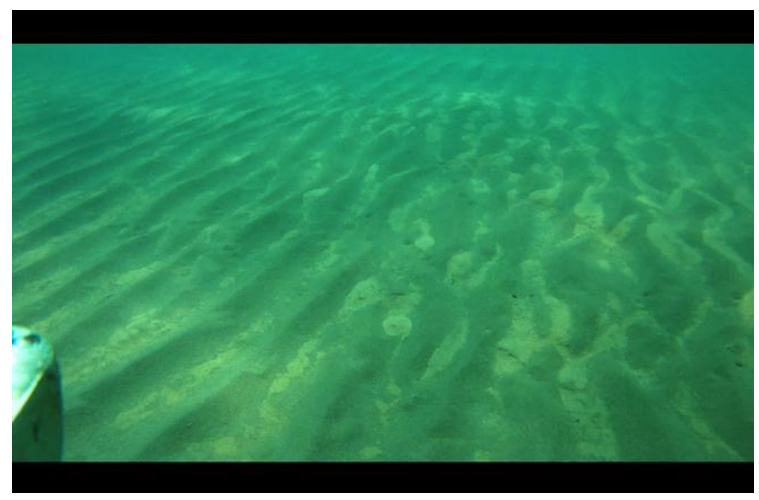

(c)

The biological effects of stamp sand encroachment could create several direct and indirect effects. The direct effects are toxic copper impacts on benthic algae, benthic invertebrates and fish. The indirect effects are physical, e.g., stamp sands filling in crevices in boulder fields, reducing the breeding field options and area. With beach seine samples, Bill Mattes (GLIFWC) has documented abundant lake whitefish fry along the white sandy beach, but none along the comparable stamp sand beach stretches. We suggest that whitefish (and all other species) are absent because copper kills 
benthic organisms (algae and invertebrates) directly, eliminating both invertebrates and their food (algae).

Secondly, toxic effects upon periphyton communities (Figure 12a-c) could indirectly limit benthic invertebrates, by indirectly reducing their resources. Fish would avoid the stamp sand regions, because there are no invertebrates, i.e., food or resources. Thirdly, fish may sense copper concentrations directly and avoid regions with high concentrations. Underwater photographs of stamp sand ripples show a white floc (Figure 12c; site 5 in Figure 5) that settles into depressions between ripples. This floc is composed of initially living periphyton sloughed off boulders and cobbles from the Buffalo Reef cobble field, but is usually dead in the stamp sand ripples. In untouched boulder/cobble fields, flocs of living periphyton slough off to deposit between rocks, enhancing food for invertebrate fauna.

Figure 13. A major decrease in benthic organism density (Ponar samples) with an increase in stamp sand content ( $0 \%$ stamp sands, left panel; $0 \%-25 \%$ in the two middle left panels, $25 \%-75 \%$ in the middle right panel and $75 \%-100 \%$ on the far right panel). The bars give a mean density of $\pm 95 \%$ C.L.; individual taxa are listed in the insert.

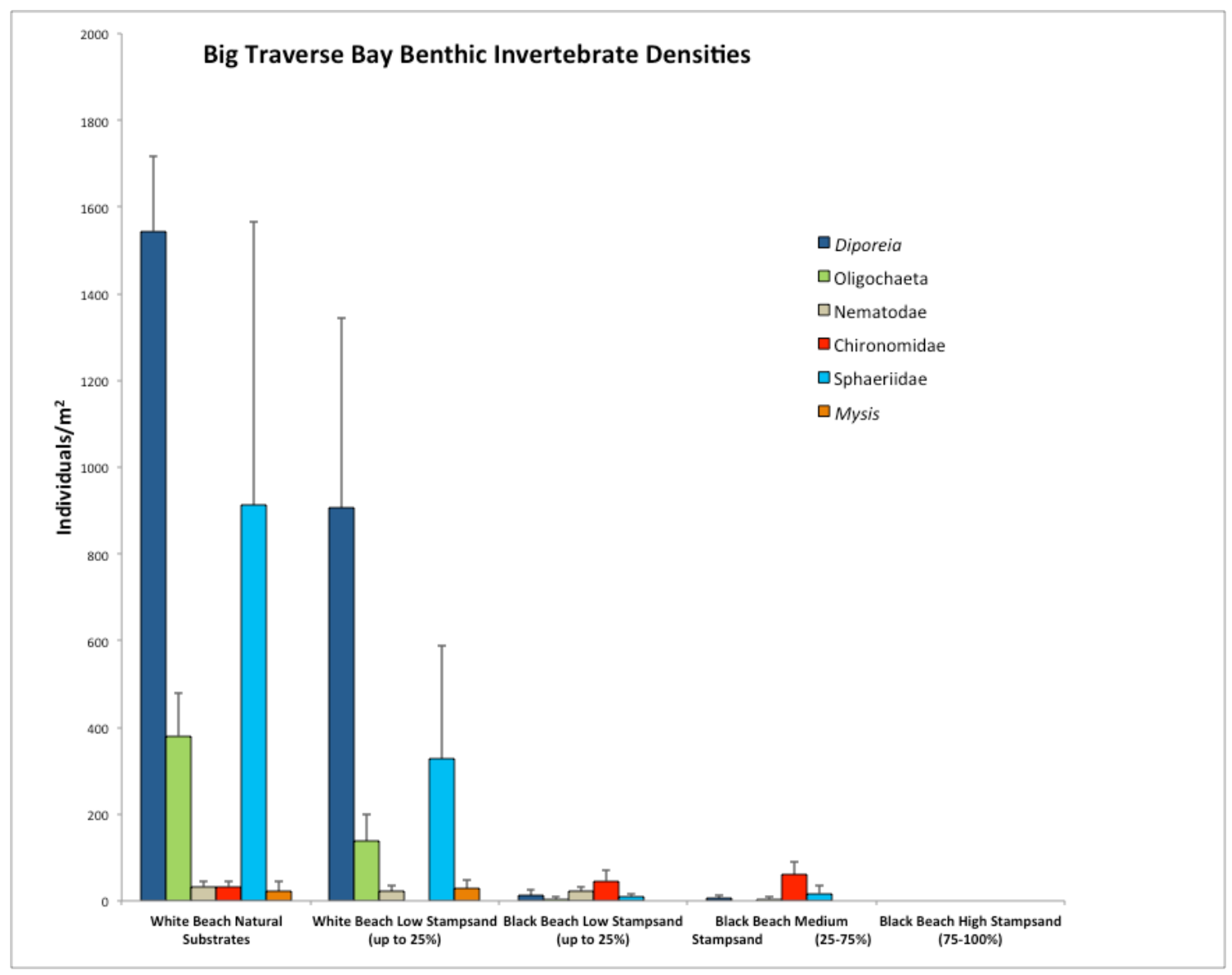

Continuing Ponar sampling efforts are quantifying impacts on benthic organisms. Benthic surveys based on Ponar sampling are now confirming a severe reduction or absence of organisms where stamp sands are abundant (Figure 13). In addition to Buffalo Reef as a unique lake trout and lake whitefish spawning ground, the southwestern white beach section of the bay is an important "rearing ground" for lake whitefish. If stamp sands create a biological "desert", as previously suggested by Kraft [42] for 
the western coastal region of the Keweenaw Peninsula, then there is great concern for the environmental effects in Grand (Big) Traverse Bay.

\section{Discussion}

\subsection{Evaluation of the Combined LiDAR and MSS Approach to Coastal Tailing Discharges}

One major aim of the investigation was to evaluate the application of airborne LiDAR and MSS for generating environmentally useful information on coastal zone mine tailing discharges. CHARTS LiDAR produced excellent resolution of coastal elevation and bathymetric surfaces down to $22 \mathrm{~m}$ below the water level. When combined with historic aerial photography (1938-present) and an early (1906) bathymetry map, we were able to reconstruct the erosion of the primary pile and to quantify the shoreline spread of tailings along the coastal zone. Regression fits provided error estimates of historic mass loss from the pile and corresponding mass accumulation along the southwestern beach margins.

LiDAR revealed migrating underwater bars and fields of stamp sands. However, conclusively verifying that stamp sands were present required MSS, underwater video and Ponar sampling techniques. The passive CASI 1500 is a hyperspectral scanner that was used here in multispectral mode (MSS 2008 eight-band; i.e., broad-band), along with MSS NAIP (2005, 2009 three-band) images. The main focus was on using the refracted green to red portion of the visible spectrum $(495-750 \mathrm{~nm})$ to detect stamp sands underwater and to characterize benthic sediment types. Using the Lyzenga [37] technique, the spectral bands allowed us to distinguish: (1) stamp sands migrating from the primary discharge pile; (2) native beach and coastal sands; and (3) Jacobsville Sandstone bedrock. The resulting substrate classification corresponded closely to independent sonar/video maps produced by NWRI (Biberhofer and Procopec [32]), although, for the first time, we were able to map stamp sands along the coastal zone. We showed that stamp sands were surrounding Buffalo Reef and that portions were actively encroaching into boulder fields. Future work will involve more intensive substrate sampling, dealing with mixtures of stamp sands and natural sands and the copper toxicity of these mixtures to different components of the bay food web.

\subsection{Environmental Effects along the Keweenaw Coastline}

Previous toxicological characterizations have investigated stamp sand ponds and beaches south of Gay and provide insight into potential environmental effects. Pond waters formed in coastal stamp sand beach deposits were found to be toxic to aquatic organisms and severely depressed in species diversity $[43,44]$. At Gay, groundwater samples from stamp piles contained $\mathrm{Cu}$ concentrations of $670 \mu \mathrm{g} \cdot \mathrm{L}^{-1}$ (parts per billion; [18]) and 250-22,000 $\mu \mathrm{g} \cdot \mathrm{L}^{-1}$ [20], whereas dissolved $\mathrm{Cu}$ concentrations in pond waters on the stamp sands ranged between 10 and $2,400 \mu \mathrm{g} \cdot \mathrm{L}^{-1}[18,44]$. Native water fleas (Daphnia pulex) suspended in coastal stamp sand pools died after 2-12 days [44,45], as opposed to $80 \%$ survival in nearby natural forest pond waters. That stamp sand pools had severely reduced biological diversity is hardly surprising, since upper toxicity thresholds $\left(\mathrm{LC}_{50}\right)$ for freshwater organisms usually lie between 12 and $600 \mu \mathrm{g} \cdot \mathrm{L}^{-1}$ dissolved $\mathrm{Cu}$ [46]. The native Daphnia pulex was sensitive to $\mathrm{Cu}$ concentrations above $12 \mu \mathrm{g} \cdot \mathrm{L}^{-1}$, two orders of magnitude below $\mathrm{Cu}$ water concentrations in the ponds [44], yet close to Michigan State dissolved $\mathrm{Cu}$ action levels. 
In 2003, MDEQ obtained 24 surface "soil" samples from redeposited stamp sand south of the main pile ("southern site") and 274 soil samples and 10 groundwater samples from the original northern pile ("northern site"; Weston 2007). Table 3 summarizes the findings of elements that exceed the State Groundwater Surface Water Interface Criteria (GSWIC). The highest risk came from copper, but seven other metals (Al, Cr, Co, Mn, Ni, Ag and Zn) also exceeded standards 29\%-100\% of the time.

Table 3. Elements that exceed Michigan State Groundwater Surface Interface Criteria (GSWIC). Total stamp sand samples are listed in the first row entries, whereas the number of samples that exceeded the elemental GSWIC criteria and their percent are listed in the lower portion of the table.

\begin{tabular}{|c|c|c|c|c|c|c|}
\hline GSWIC Summary & & Southern Site & & Northern Site & & Groundwater \\
\hline Samples taken & & 24 & & 274 & & 10 \\
\hline Element & Number & $\%$ & Number & $\%$ & Number & $\%$ \\
\hline Aluminum (Al) & 20 & 83 & 271 & 99 & $\mathrm{DNE}^{*}$ & \\
\hline Chromium (Cr) & 19 & 79 & 65 & 24 & 5 & 50 \\
\hline Cobalt (Co) & 24 & 100 & 271 & 99 & DNE * & \\
\hline Copper $(\mathrm{Cu})$ & 24 & 100 & 274 & 100 & 10 & 100 \\
\hline Manganese (Mn) & 7 & 29 & 159 & 58 & 5 & 50 \\
\hline Nickel (Ni) & 8 & 33 & 168 & 61 & 8 & 80 \\
\hline Silver & 9 & 38 & 216 & 79 & 8 & 80 \\
\hline Zinc $(\mathrm{Zn})$ & 10 & 42 & 242 & 88 & 8 & 80 \\
\hline
\end{tabular}

$* \mathrm{DNE}=$ did not exceed.

Coastal regions off stamp sand piles on the Keweenaw Peninsula are characterized by a reduced diversity of benthic macroinvertebrates [42,47]. The freshly worked stamp sand and lake sediments are toxic to Daphnia and mayflies (Hexagenia), because they release $\mathrm{Cu}$ across the pore-water gradient [19]. Additional laboratory EPA toxicity experiments with slime-clay-rich lake sediments from the Keweenaw Waterway and Torch Lake showed that solid-phase sediments and aqueous fractions (e.g., interstitial water) associated with the slime-clay sediments were lethal to several taxa of freshwater macroinvertebrates: chironomids (Chironomus tentans), oligochaetes (Lumbriculus variegates), amphipods (Hyalella azteca) and cladocerans (Ceriodaphnia dubia). Moreover, the observed toxicity was due to dissolved copper, as opposed to other metals (principally zinc and lead) present in the sediments [48-50]. These laboratory tests were consistent with field observations of stamp sand effects on benthic organisms, where an increase in the percent of stamp sands suppressed a wide variety of taxa (Figure 13).

Bioassay tests conducted by Weston on Gay stamp sands for the MDEQ also indicated that the Gay stamp sands were toxic to benthic organisms [38]. Moreover, the tailings pile at Gay contained metals above the levels permissible for direct contact with humans, was capable of leaching metals to the groundwater that exceeded drinking water standards and was toxic to aquatic life [38]. Recent coastal water and sediment studies conducted by MDEQ [51] found elevated copper concentrations $(1,500-8,500 \mathrm{ppm})$ in sediment at six sites immediately off stamp sand beaches and found three of eight water column samples taken off beach margins to be also elevated in dissolved copper (4-55 ppb). State water quality standards (WQS) for dissolved copper are chronic (4.53 ppb) and acute (12.7 ppb). 
Three sediment samples immediately south of the Traverse River Seawall, off the white beach, also contained elevated copper (79-400 ppm), illustrating the environmental effects of sediment movement around the seawall barrier. Bulk sediment toxicity testing using a chironomid (Chironomus dilutus) and an amphipod (Hyalella azteca) showed that all sediment samples, including off the white beach near the seawall, were acutely toxic to the two test organisms.

\subsection{Potential Economic Consequences of Buffalo Reef Collapse}

The Bad River, Red Cliff and Keweenaw Bay tribes retain rights to harvest fish from the Michigan waters of Lake Superior under the 1,842 and 1,854 treaties. A preliminary assessment of the fishery by Bill Mattes, GLIFWC's Great Lakes Section Leader, suggests that the loss of Buffalo Reef spawning would reduce lake trout and whitefish harvesting by $23 \%$ (around $67,222 \mathrm{~kg}$ of whitefish and $31,946 \mathrm{~kg}$ of lake trout per year). The dockside value for the tribal commercial fishery would be $\$ 191,023$ (i.e., $\$ 2.49 / \mathrm{kg} \times 67,222 \mathrm{~kg}$ for whitefish and $\$ 0.74 / \mathrm{kg} \times 31,946 \mathrm{~kg}$ for lake trout per year). In addition, recreational fishing in the area generated $\$ 68,360$ during 2010 (an estimated $\$ 30 / 24 \mathrm{~h} \times 54,688$ fishing $\mathrm{h}$ ). The combined estimated total annual value from fishing would be about $\$ 259,000$. Cascading effects could add far more expenses. For example, GLIFWC estimates that stocking lake trout to replace lost natural reproduction would cost around $\$ 380,000$ annually. The economic displacement of 10.4 tribal fishing jobs at $\$ 100,000$ annually (personnel plus equipment) for $10-11$ years could be around $\$ 11 \mathrm{M}$.

\subsection{Regional and Global Concerns about Coastal Tailing Discharges}

Between 1850 and 1968, copper ore processing on the Keweenaw Peninsula discharged around 360 million metric tons of stamp sand tailings along shorelines, connecting waterways and into interior lakes and rivers [3,8]. Another well-documented Great Lakes case that affected Lake Superior sediments featured the discharge of taconite (iron) tailings north of Duluth, Minnesota. Taconite plants mix iron ore with clay, producing a pellet suited for blast furnaces. Most operating iron mines in the Lake Superior Basin are inland, with tailing piles located near open pit excavations. However, between 1955 and 1980, 500 Mt of taconite tailings were sluiced into Silver Bay, along the North Shore of Minnesota. Iron-rich sediments moved into the Duluth Basin, beyond the confines of the $23.3 \mathrm{~km}^{2}$ permitted dumping site. Small asbestiform particles (cummingtonite) from the discharge subsequently spread along the coast down to the Duluth water intake site and over three western basins of Lake Superior (Duluth, Chefswet and Thunder Bay Basins). The affected area eventually extended over a hundred kilometers from the original discharge site [52,53]. The 1972 Clean Water Act of the US and Canada now bans coastal mining discharges. However, lingering effects come from tailing piles and tailings pond failures. At Elliot Lake, north of Lake Huron, more than 30 tailings pond failures at 14 uranium mining operations have been recorded, prompting the International Joint Commission to describe the drainage system as a major source of radium contamination in the Great Lakes [54]. The region contains nearly $165 \mathrm{Mt}$ of heavy-metal laced tailings, with the principle concerns centering on thorium and radium.

Yet, what we discuss as examples in the northern Great Lakes are but the tip of the iceberg, as the boom and bust cycles of mining have produced unattended mine shafts, tailings piles, cofferdams 
and holding ponds throughout northern US and Canadian watersheds. Moreover, the Great Lakes problems are symptomatic of a substantial coastal problem present around the globe. There are numerous examples of past and present mine disposal into freshwater and marine coastal environments. Coastal disposal sites are widely spread across North America (Canada, USA), South America (El Salvador, Chile), Northern Europe (Norway, Britain), the Mediterranean (Spain, Turkey), Africa, Indonesia, Papua New Guinea, Philippines and Toga.

Despite great expressed concern [55,56], marine coastal deposition continues to be advocated in recent mining bulletins [57-59] as a simple way of disposing of tailings. Advocacy utilizes the following arguments. On-land tailings disposal generally involves the construction of a dam in stream drainage, or an enclosure on gently sloping terrain, which is used to impound tailings. These containment structures are often the largest surface features of a mine, flooding hundreds of hectares and adversely affecting the terrestrial environment. Moreover, tailings impoundments are usually left in place after mining has ceased and require perpetual inspection and maintenance. An estimated 3,500 mine tailings impoundments/dams exist world-wide [60]. These impoundments are prone to severe climatic and seismic events, leading to unexpected catastrophic failure and widespread environmental "catastrophes" (e.g., the "Aznalcollar Disaster", Guadalquivir Estuary, Spain [61]; the "Marcopper Mining Disaster", Calancan Bay, Marinduque Island, Philippines [62]). For example, along the Mediterranean coast, there are over 230 tailings dams in the Spanish Province of Almeria alone, dating back to Roman times [55]. As an alternative, mining documents suggest that tailings discharged along coastal margins have minimal terrestrial affects and disappear underwater, moving "out of sight, out of mind". Our point is that, unattended, they will move across large regions of bays, greatly expanding environmental effects beyond the area of the original tailing deposition. The issue of coastal tailings disposal is emerging as a great concern for oceanography and was recently reviewed in a report entitled "International Assessment of Marine and Riverine Disposal of Mine Tailings" commissioned by the International Maritime Organization and the United Nations Environment Program, Global Program of Action [60].

Given the global incidence of coastal mine discharges and the concern over how long these effects will play out over extended time periods, one can easily envision how combined LiDAR and MSS or hyperspectral coastal imaging provides valuable information regarding the spread of past mining discharges along shallow stretches of coastal shorelines and ecosystem effects. The ability to discriminate between sediment types has equal value in studies of coastal tailings impoundment failures. However, if the discharges are placed, or move, into waters greater than $22-40 \mathrm{~m}$, beyond reflectance limits, then alternative tracking methods must be employed. Concerns about stamp sand migration from the Gay pile, aided by preliminary LiDAR and MSS imagery, spurred the United States Army Corps of Engineers (USACE) Detroit District Office, in February 2011, to authorize a US\$8-9 million dollar Keweenaw Stamp Sands Ecosystem Restoration Plan for Grand (Big) Traverse Bay.

\section{Conclusions}

CHARTS LiDAR/MSS overflights provide valuable high-resolution studies of tailings movement along the Grand (Big) Traverse coastal region. With LiDAR, the old axiom "out of sight, out of mind", 
no longer applies. Data from the combined four CHARTS fly-overs have allowed for direct estimates of above- and below-water stamp sand movement along the coastal margin, documented underwater movement into the "trough" northeast of Buffalo Reef and helped clarify and quantify the threat to Buffalo Reef. Just as important, the detailed imaging will assist planned revetment, groin and sea wall construction efforts by providing up-to-date topographic and bathymetric information. The LiDAR overflights have provided invaluable information for estimating aerial coverage and shoreline volumes and have real promise for assisting hydrodynamic modeling efforts by providing images for the "difference" calculations of underwater stamp sand bar movement. Yet, more precise detail is needed around Buffalo Reef on stamp sand volume (the layer thickness in the "trough") before the "trough" dredging option can be evaluated for protecting Buffalo Reef. Moreover, the statement has been made that "the horses may have left the barn", because there is now twice as much stamp sand on beaches south of the pile than remaining on the original pile (i.e., $7 \mathrm{Mt} v$ s. $3 \mathrm{Mt}$ ). What mix of mitigation measures may address the present-day distribution of stamp sands? With LiDAR and MSS mosaics, we provide up-to-date information for alternatives. Benthic and ROV surveys, which show boulder field details and provide direct evidence for stamp sand encroachment, are beginning to answer critical questions about the percentage of encroachment of stamp sands into the northern and middle reaches of the Buffalo Reef boulder/cobble fields and about the impacts upon organisms. If stamp sands are creating a biological "desert", then perhaps, stamp sand cover mosaics can be translated easily into environmental impacts. Even more intriguing, one could ask how the invading stamp sands will ultimately influence normal breeding activity and the survival of fish on the reef.

Mine wastes are identified in the Lake Superior Lake-wide Management Plan (LaMP) as a principal stress to the aquatic habitat in Lake Superior. The recently announced "Keweenaw Stamp Sands Ecosystem Restoration Project" (February 2011, Detroit Army Corps) provides an excellent opportunity to demonstrate how to implement LaMP priority projects by better integrating agency, institutional and local political approaches. Previous legacy mining efforts in Michigan have been focused on inland sites (the Torch Lake, Portage Lake and Deer Lake "areas of concern") or the Minnesota efforts on amphibole-like particles (Silver Bay, MN, taconite discharges). The entire issue of what to do with tailings discharges (piles or ponds) is a major issue for both regulatory agencies, as well as for the mining industry. The project also bridges another delicate issue: water column jurisdiction by tribal treaty versus state jurisdiction over sediments. The threat to Buffalo Reef cuts across tribal and state jurisdictions, whereas the metal "halo" issue around the Keweenaw Peninsula potentially influences large portions of Lake Superior in yet undisclosed ways. Certainly, curtailing the tailings dispersal effects is a good first step.

\section{Acknowledgments}

Primary funding for LiDAR/MSS investigations came from the Army Corps of Engineers ERDC-EL laboratory and was provided by the System Wide Water Resources Program (Steve Ashby) at Vicksburg, MS. Efforts were also aided by a National Science Foundation OCE 97-12872 grant to W. Charles Kerfoot, and a US Environmental Protection Agency Region V Grant to the Baraga Tribal Council passed through to W. Charles Kerfoot Support for the CHARTS flight and initial data processing was provided by the Corps National Coastal Mapping Program managed by Jennifer 
Wozencraft at the JALBTCX Center. We thank Dave Schwab, NOAA GLERL, Ann Arbor, for assistance on the NOAA LiDAR series overflight and coastal forecast information. We also thank Esteban Chiriboga and especially Hans Biberhofer for sharing the details of the National Water Research Institute and Great Lakes Indian Fish and Wildlife Commission sonar mapping and sediment sampling efforts in Grand (Big) Traverse Bay. We also want to recognize ROV and sampling efforts by Jade Ortiz, Nathan Zgniler, and Aaron Garceau in summer, 2013. Lucille Zelazny proofread the manuscript and aided in preparation of figures.

\section{Author Contributions}

Research was conducted under, and article largely written by, W. Charles Kerfoot. LiDAR specifics were contributed by Molly Reif, Foad Yousef, Robert Shuchman, and Colin Brooks. The MSS substrate classification was provided by Foad Yousef and Sarah Green. Field ROV and side-scan sonar image portions were done with Jamey Anderson and Martin Hobmeier. Ponar sampling for sediment ground-truth and benthos community was carried out by Martin Hobmeier and Foad Yousef. Updated estimates of tailings pile erosion and beach deposition were calculated by Foad Yousef, with assistance from Robert Regis.

\section{Conflicts of Interest}

The authors declare no conflict of interest.

\section{References}

1. Ackermann, F. Airborne laser scanning-present status and future expectations. J. Photogram. Remote Sens. 1999, 54, 64-67.

2. Crow, P.; Benham, S.; Devereux, B.J.; Amable, G.S. Woodland vegetation and its implications for archaeological survey using LiDAR. Forestry 2007, 80, 241-252.

3. Kerfoot, W.C.; Yousef, F.; Green, S.A.; Regis, R.; Shuchman, R.; Brooks, C.N.; Sayers, M.; Sabol, B.; Graves, M. LiDAR (Light Detection and Ranging) and multispectral studies of disturbed Lake Superior coastal environments. Limnol. Oceanogr. 2012, 57, 749-771.

4. Banks, K.W.; Riegl, B.; Shinn, E.A.; Piller, W.E.; Dodge, R.E. Geomorphology of the Southeast Florida continental reef tract (Miami-Dade, Broward, and Palm Beach Counties, USA). Coral Reefs 2007, 26, 617-633.

5. United States Environmental Protection Agency. Studies Regarding the Effect of the Reserve Mining Company Discharge on Lake Superior; Office of General Enforcement \& Council: Washington, DC, USA, 1973.

6. Kemp, A.L.W.; Williams, J.D.H.; Thomas, R.L.; Gregory, M.L. Impact of man's activities on the chemical composition of the sediments of Lakes Superior and Huron. Water Air Soil Pollut. 1978, 10, 381-402.

7. Kerfoot, W.C.; Nriagu, J.O. Copper mining, copper cycling and mercury in the Lake Superior ecosystem: An introduction. J. Great Lakes Res. 1999, 25, 594-598. 
8. Kerfoot, W.C.; Jeong, J.; Robbins, J.A. Lake Superior Mining and the Proposed Mercury Zero-Discharge Region. In State of Lake Superior; Munawar, M., Ed.; Noida Goodword Books: New Delhi, India, 2009; pp. 153-216.

9. Kerfoot, W.C.; Lauster, G.; Robbins, J.A. Paleolimnological study of copper mining around Lake Superior: Artificial varves from Portage Lake provide a high resolution record. Limnol. Oceanogr. 1994, 39, 649-669.

10. Kolak, J.J.; Long, D.T.; Kerfoot, W.C.; Beals, T.M.; Eisenreich, S.J. Nearshore versus offshore copper loading in Lake Superior sediments: Implications for transport and cycling. J. Great Lakes Res. 1999, 25, 611-624.

11. Gewurtz, S.B.; Shen, L.; Helm, P.A.; Waltho, J.; Reiner, E.J.; Painter, S.; Brindle, I.D.; Marvin, C.H. Spatial distributions of legacy contaminants in sediments of lakes Huron and Superior. J. Great Lakes Res. 2008, 34, 153-168.

12. LaRocque, P.E.; West, G.R. Airborne Laser Hydrography: An Introduction. In Proceedings of ROPME/PERSGA/IHB Workshop on Hydrographic Activities in the ROPME Sea Area and Red Sea, Kuwait City, Kuwait, 24-27 October 1990.

13. Murdoch, W.A. Boom Copper: The Story of the First United States Mining Boom; MacMillan: New York, NY, USA, 1943.

14. Benedict, C.H. Lake Superior Milling Practice; Michigan College of Mining and Technology: Houghton, MI, USA, 1955.

15. Kerfoot, W.C.; Harting, S.L.; Jeong, J.; Robbins, J.A.; Rossmann, R. Local, regional and global implications of elemental mercury in metal (copper, silver, gold, and zinc) ores: Insights from Lake Superior sediments. J. Great Lakes Res. 2004, 52, 162-184.

16. Butler, B.S.; Burbank, W.S. The Copper Deposits of Michigan; US Government Printing Office: Washington, DC, USA, 1929.

17. Babcock, L.L.; Spiroff, K. Recovery of Copper from Michigan Stamp Sands; US Bureau of Mines Project G0180241 (SWD-18); Michigan Technological University: Houghton, MI, USA, 1970; Volume 1, p. 57.

18. Jeong, J.; Urban, N.R.; Green, S. Release of copper from mine tailings on the Keweenaw Peninsula. J. Great Lakes Res. 1999, 25, 721-734.

19. Malueg, K.W.; Schuytema, G.S.; Krawczyk, D.F.; Gakstatter, J.H. Laboratory sediment toxicity tests, sediment chemistry and distribution of benthic macroinvertebrates in sediments from the Keweenaw Waterway, Michigan. Environ. Toxicol. Chem. 1984, 3, 233-242.

20. MDEQ. Toxicological Evaluation for the Gay, Michigan Stamp Sand; Weston Solutions: Houghton, MI, USA, 2006.

21. Kerfoot, W.C.; Robbins, J.A. Nearshore regions of Lake Superior: Multi-element signatures of mining discharges and a test of $\mathrm{Pb}-210$ deposition under conditions of variable sediment mass flux. J. Great Lakes Res. 1999, 25, 611-624.

22. Goodyear, C.S.; Edsall, T.A.; Ormsby, D.M.; Dempsey, D.M.O.; Moss, G.D.; Polanski, P.E. Atlas of the Spawning and Nursery Areas of Great Lakes Fishes; United States Fish and Wildlife Service: Daphne, AL, USA, 1982.

23. Chiriboga, E.D.; Mattes, W.P. Buffalo Reef and Substrate Mapping Project; Administrative Report 08-04; Great Lakes Indian Fish and Wildlife Commission (GLIFWC): Odanah, WI, USA, 2008. 
24. Mazina'igan. A Chronicle of the Lake Superior Ojibwe; Great Lakes Indian Fish and Wildlife Commission: Odanah, WI, USA, 2007.

25. Reif, M.K.; Wozencraft, J.M.; Dunkin, L.M.; Sylvester, C.S.; Macon, C.L. A review of US Army Corps of Engineers airborne coastal mapping in the Great Lakes. J. Great Lakes Res. 2013, 39, 194-204.

26. Wozencraft, J.M. Complete Coastal Mapping with Airborne Lidar. In Proceedings of the Oceans MTS/IEEE, Biloxi, MS, USA, 29-31 October 2002; Volume 2, pp. 1194-1198.

27. Wozencraft, J.M.; Lillycrop, J.W. JALBTCX coastal mapping for rthe USACE. Int. Hydrogr. Rev. 2006, 7, 28-37.

28. LaRocque, P.E.; Banic, J.R.; Cunningham, A.G. Design description and field testing of the SHOALS-1000T airborne bathymeter. SPIE 2004, doi:10.1117/12.564924.

29. Lillesand, T.M.; Kiefer, R.W.; Chipman, J.W. Remote Sensing and Image Interpretation, 6th ed.; John Wiley \& Sons: Hoboken, NJ, USA, 2008.

30. Hedley, J.D.; Harborne, A.R.; Mumby, P.J. Simple and robust removal of sun glint for mapping shallow-water benthos. Int. J. Remote Sens. 2005, 26, 2107-2112.

31. Yousef, F.; Kerfoot, W.C.; Brooks, C.N.; Shuchman, R.; Sabol, B.; Graves, M. Using LiDAR to reconstruct the history of a coastal environment influenced by legacy mining. J. Great Lakes Res. 2013, 39, 205-216.

32. Biberhofer, J.; Procopec, C.M. Delineation and Characterization of Aquatic Substrate Features on or Adjacent to Buffalo Reef, Keweenaw Bay, Lake Superior; Technical Note AERMB-TN06; Environment Canada National Water Resource Institute (NWRI): Burlington, ON, Canada, 2008.

33. Jensen, J.R. Introductory Digital Image Processing: A Remote Sensing Perspective, 3rd ed.; Prentice Hall PTR: Upper Saddle River, NJ, USA, 2004.

34. Lam, D.C. Simulation of water circulation and chloride transports in Lake Superior for summer 1973. J. Great Lakes Res. 1978, 4, 343-349.

35. Chen, C.; Zhu, J.; Ralph, E.; Green, S.A.; Wells Budd, J.; Zhang, F.Y. Prognostic modeling studies of the Keweenaw current in Lake Superior. Part I: Formation and evolution. J. Phys. Oceanogr. 2001, 31, 379-395.

36. Sabol, B.; Lord, E.; Reine, K.; Shafer, D. Comparison of Acoustic and Aerial Photographic Methods for Quantifying the Distribution of Submersed Aquatic Vegetation in Sagamore Creek, NH; ERDC TN-DOER-E23; US Army Engineer Research and Development Center: Vicksburg, MS, USA, 2008.

37. Lyzenga, D.R. Remote sensing of bottom reflectance and water attenuation parameters in shallow water using aircraft and Landsat data. Int. J. Remote Sens. 1981, 2, 71-82.

38. Weston Solutions of Michigan, Inc. Migrating Stamp Sand Migration Plan Technical Evaluation; Remediation and Redevelopment Division: Chilton, MI, USA, 2007.

39. Sloss, P.W.; Saylor, J.H. Large-Scale Current Measurements in Lake Superior; NOAA Technical Report ERL 363-GLERL 8; Great Lakes Environmental Research Laboratory: Ann Arbor, MI, USA, 1976.

40. Zhu, J.; Chen, C.; Ralph, E.; Green, S.A.; Budd, J.W.; Zhang, F.Y. Prognostic modeling studies of the Keweenaw current in Lake Superior. Part II: Simulation. J. Phys. Oceanogr. 2001, 31, 396-410. 
41. Rasmussen, T.; Fraser, R.; Lemberg, D.S.; Regis, R. Mapping stamp sand dynamics: Gay, Michigan. J. Great Lakes Res. 2002, 28, 276-284.

42. Kraft, K.J. Pontoporeia distribution along the Keweenaw shore of Lake Superior affected by copper tailings. J. Great Lakes Res. 1979, 7, 258-263.

43. Kerfoot, W.C.; Harting, S.; Rossmann, R.; Robbins, J.A. Anthropogenic copper inventories and mercury profiles from Lake Superior: Evidence for mining impacts. J. Great Lakes Res. 1999, 25, 663-682.

44. Lytle, R.D. In situ copper toxicity tests: Applying likelihood ratio tests to Daphnia pulex incubations in Keeweenaw Peninsula waters. J. Great Lakes Res. 1999, 25, 744-759.

45. Kerfoot, W.C.; Robbins, J.A.; Weider, L.J. A new approach to historical reconstruction: Combining descriptive and experimental paleolimnology. Limnol. Oceanogr. 1999, 44, 1232-1247.

46. United States Environmental Protection Agency. Integrated Risk Assessment System (IRIS); US Environmental Protection Agency: Washington, DC, USA. 1992.

47. Kraft, K.J.; Sypniewski, R.H. Effect of sediment copper on the distribution of benthic macroinvertebrates in the Keweenaw Waterway. J. Great Lakes Res. 1981, 7, 258-263.

48. Ankley, G.T.; Mattson, V.R.; Leonard, E.N.; West, C.W.; Bennett, J.L. Predicting the acute toxicity of copper in freshwater sediments: Evaluation of the role of acid volatile sulfide. Environ. Toxicol. Chem. 1993, 11, 315-320.

49. Schubauer-Berigan, M.K.; Dierkes, J.R.; Monson, P.D.; Ankley, G.T. pH-dependent toxicity of $\mathrm{Cd}, \mathrm{Cu}, \mathrm{Ni}, \mathrm{Pb}$, and $\mathrm{Zn}$ to Ceriodaphnia dubia, Pimephales promelas, Hyalella azteca and Lumbriculus variegates. Environ. Toxicol. Chem. 1993, 12, 1261-1266.

50. West, C.W.; Mattson, V.R.; Leonard, E.N.; Phipps, G.L.; Ankley, G.T. Comparison of the relative sensitivity of three benthic invertebrates to copper contaminated sediments from the Keweenaw Waterway. Hydrobiologia 1993, 262, 57-68.

51. Michigan Department Of Environmental Quality. A Sediment Chemistry of Lake Superior Shoreline in the Vicinity of Gay, Keweenaw and Houghton Counties, Michigan August 26, 27, and 28, 2008; Michigan Department Of Environmental Quality: Lansing, MI, USA, 2012.

52. Cook, P.M.; Glass, G.E., Tucker, J.H. Asbestiform amphibole minerals: Detection and measurement of high concentrations in municipal water supplies. Science 1974, 185, 853-855.

53. International Joint Commission. Great Lakes Water Quality, 1977 Annual Report; Great Lakes Water Quality Board: Windsor, ON, USA, 1977.

54. Wynn, G. Canada and Arctic North America: An Environmental History; ABC-CILO, Inc.: Santa Barbara, CA, USA. 2007.

55. Martinez-Frias, J. Mine waste pollutes Mediterranean. Nature 1997, 388, 120.

56. Moran, R.; Reichelt-Brushett, A.; Young, R. Out of sight, out of mine: Ocean dumping of mine wastes; The world's oceans, already imperiled, face a new threat. WorldWatch 2009, 22, 30-34.

57. Coldwell, J.R.; Gensler, E.C. Potential for Submarine Tailings Disposal to Affect the Availability of Minerals from United States Coastal Areas; Open File Report 101-93; US Bureau of Mines: Juneau, AK, USA, 1993.

58. Ellis, D.V.; Robertson, J.D. Underwater Placement of Mine Tailings: Case Examples and Principles. In Environmental Impacts of Mining Activities; Azcue, J.M., Ed.; Springer Verlag: Berlin/Heidelberg, Germany, 1999; pp. 123-141. 
59. Younger, P.L. Towards regulatory criteria for discharging iron-rich mine water into the sea. Mine Water Environ. 2008, 27, 56-61.

60. Vogt, C. International Assessment Of Marine and Riverine Disposal of Mine Tailings. In Proceedings of the Secretariat, London Convention/London Protocol, International Maritime Organization, London, England \& United Nations Environment Programme-Global Program of Action, London, UK, 1 November 2012; p. 134.

61. Grimalt, J.O.; Ferrer, M.; Macpherson, E. The mine tailing accident in Aznalcollar. Sci. Total Environ. 1999, 242, 3-11.

62. Marges, M.; Su, G.S.; Ragragio, E. Assessing heavy metals in the waters and soils of Calancan Bay, Marinduque Island, Philippines. J. Appl. Sci. Environ. Sanit. 2011, 6, 45-49.

(C) 2014 by the authors; licensee MDPI, Basel, Switzerland. This article is an open access article distributed under the terms and conditions of the Creative Commons Attribution license (http://creativecommons.org/licenses/by/3.0/). 